This article is published as: Maetens, W., Poesen, J. and Vanmaercke, M., 2012. How effective are soil conservation techniques in reducing plot runoff and soil loss in Europe and the Mediterranean? Earth-Science Reviews 115(1-2): 21-36. doi:10.1016/j.earscirev.2012.08.003

\title{
How effective are soil conservation techniques in reducing plot runoff and soil loss in Europe and the Mediterranean?
}

\author{
W. Maetens ${ }^{*}, 1$, J. Poesen ${ }^{1}$, M. Vanmaercke ${ }^{1,2}$
}

1 Division of Geography, Department of Earth and Environmental Sciences, KU Leuven, Celestijnenlaan 200E, B-3001 Heverlee, Belgium

${ }^{2}$ Research Foundation Flanders (FWO), Belgium

\begin{abstract}
The effects of soil and water conservation techniques (SWCTs) on annual runoff $\left(\mathrm{R}_{a}\right)$, runoff coefficients $\left(\mathrm{RC}_{a}\right)$ and annual soil loss $\left(\mathrm{SL}_{a}\right)$ at the plot scale have been extensively tested on field runoff plots in Europe and the Mediterranean. Nevertheless, a comprehensive overview of these effects and the factors controlling the effectiveness of SWCTs is lacking. Especially the effectiveness of SWCT in reducing $\mathrm{R}_{a}$ is poorly understood. Therefore, an extensive literature review is presented that compiles the results of 101 earlier studies. In each of these studies, $\mathrm{R}_{a}$ and $\mathrm{SL}_{a}$ was measured on field runoff plots where various SWCTs were tested. In total, 353 runoff plots (corresponding to 2093 plot-years of data) for 103 plot-measuring stations throughout Europe and the Mediterranean were considered. SWCTs include (1) crop and vegetation management (i.e. cover crops, mulching, grass buffer strips, strip cropping and exclosure), (2) soil management (i.e. no-tillage, reduced tillage, contour tillage, deep tillage, drainage and soil amendment) and (3) mechanical methods (i.e. terraces, contour bunds and geotextiles). Comparison of the frequency distributions of $\mathrm{SL}_{a}$ rates on cropland without and with the application of SWCTs shows that the exceedance probability of tolerable $\mathrm{SL}_{a}$ rates is ca. $20 \%$ lower when SWCT are applied. However, no notable effect of SWCTs on the frequency distribution of $\mathrm{RC}_{a}$ is observed. For 224 runoff plots (corresponding to 1567 plot-year data), SWCT effectiveness in reducing $\mathrm{R}_{a}$ and/or $\mathrm{SL}_{a}$ could be directly calculated by comparing measured $\mathrm{R}_{a}$ and/or $\mathrm{SL}_{a}$ with values measured on a reference plot with conventional management. Crop and vegetation management techniques (i.e. buffer strips, mulching and cover crops) and mechanical techniques (i.e. geotextiles, contour bunds and terraces) are generally more effective than soil management techniques (i.e. no-tillage, reduced tillage and contour tillage). Despite being generally less effective, no-tillage, reduced tillage and contour tillage have received substantially more attention in the literature than the other SWCTs. Soil and water conservation techniques are generally less effective in reducing $\mathrm{R}_{a}$ than in reducing $\mathrm{SL}_{a}$, which is an important consideration in areas where water is a key resource and in regions susceptible to flooding. Furthermore, all SWCTs show a more consistent and effective reduction of both $\mathrm{R}_{a}$ and $\mathrm{SL}_{a}$ with increasing $\mathrm{R}_{a}$ and $\mathrm{SL}_{a}$ magnitude, which is attributed to the reduced influence of measurement uncertainties. Although some significantly negative correlations between SWCT effectiveness and plot slope length, slope gradient or annual precipitation were found, the importance of these factors in explaining the observed variability in effectiveness seems limited. Time-series analyses of $\mathrm{R}_{a}$ during multiple years of SWCT application strongly indicate that no-tillage and conservation tillage become less effective in reducing $\mathrm{R}_{a}$ over time. Such an effect is not observed for $\mathrm{SL}_{a}$.
\end{abstract}

Keywords: soil and water conservation techniques, runoff reduction, soil loss reduction, crop and vegetation management, soil management, mechanical methods

\footnotetext{
${ }^{*}$ Corresponding author:willem.maetens@ees.kuleuven.be
} 


\section{Contents}

1 Introduction 2

2 Data collection $\quad 5$

3 Characteristics of the collected plot data $\quad 6$

4 Effectiveness of SWCTs in reducing annual runoff and soil loss 10

4.1 Overall effectiveness of SWCTs . . . . . . . . . . . . . . . . . 10

4.2 Effectiveness per technique . . . . . . . . . . . . . . . . . 12

5 Factors controlling the effectiveness of SWCTs 16

6 Temporal variability and trends in the effectiveness of SWCTs 19

7 Conclusions

\section{Introduction}

Soil and Water Conservation Techniques (SWCTs) have long existed as a means to combat the detrimental effects of soil loss through interrill and rill erosion (Cerdà et al., 2009; Montgomery, 2007a; Morgan, 2005). The aim of SWCTs is to reduce both on-site runoff (R) and soil loss (SL) as well as the off-site consequences of erosion such as sedimentation of reservoirs, deterioration of water quality and flooding (e.g. Owens et al., 2005; Vanmaercke et al., 2011a; Verstraeten and Poesen, 1999). Recent research also focuses on the role of SWCTs in the conservation of various ecosystem functions of the soil and its role in bio-geochemical cycles, including carbon sequestration (e.g. Conley, 2000). Whereas the role of SWCTs in reducing soil loss is well recognised (e.g. Boardman and Poesen, 2006; Morgan, 2005), there is still a need to integrate SWCTs effectively into good agricultural and sustainable land management practices. This need is exemplified by the goals of recent policy developments such as the European Commission's Thematic Strategy for Soil Protection (European Commission, 2012). Furthermore, several international scientific projects focus on both quantifying the effectiveness of different SWCTs in reducing R and SL as well as on their successful implementation (e.g. DESIRE, 2007; Karlen, 2008; Louwagie et al., 2009; Römkens, 2010).

Successful SWCT application schemes are sufficiently effective in reducing R and SL to sustainable levels, while not being overdimensioned so that they are economically feasible. Implementing successful schemes therefore requires both qualitative assessments of the effects and applicability of SWCTs (e.g. Schwilch et al., 2011) as well as reliable quantitative data on of the R and SL reduction by the SWCT. The most widely used measure to quantify the effectiveness of SWCTs in reducing SL is the soil loss ratio (SLR), i.e. the ratio of SL from a plot with SWCT application and SL from a reference plot with the same characteristics but without SWCT application (e.g. Castillo et al., 1997; Cogo et al., 1984; Gilley and Risse, 2000; Smets et al., 2008a). SLR values are similar to the widely used (R)USLE cover management (C) and support practice (P) factor (Renard et al., 1997). However, the calculation of C- of P-factors for specific soil conservation techniques is not straightforward and the validity of the empirical relations for C- and P-factors given by Renard et al. (1997) outside the Midwestern U.S.A. is uncertain. Quantification of SWCT effectiveness for other regions requires local measurements of SLR (e.g. Hessel and Tenge, 2008). 
Furthermore, C- and P-factors apply only to SL and not to R. While runoff ratios (RR), the equivalent of SLR, have been used in some studies (e.g. Gilley and Risse, 2000), quantification of SWCT effectiveness remains mainly oriented at SL. Nevertheless, the term 'soil and water conservation techniques' implies that also an effect on runoff is expected or desired. Despite the limited attention, runoff reduction remains an important concern. On-site, conservation of plant-available water is an important issue for agricultural production (Rockström et al., 2010; Wallace, 2000) and may be a more important concern than soil loss, e.g. in areas where water is a key resource. Furthermore, sediment yield at the catchment scale is in many cases strongly controlled by the occurence and magnitude of a few flood events (e.g. Gonzalez-Hidalgo et al., 2010). Hence, runoff reduction is a crucial part of integrated catchment management (Nyssen et al., 2010; Vanmaercke et al., 2010; Verstraeten and Poesen, 1999). In addition, runoff generation and soil loss for various land use types are closely related (Maetens et al., 2012) and information on the effectiveness of SWCTs in reducing $\mathrm{R}$ can also improve insights in their effectiveness in reducing SL.

There are also strong indications that the effectiveness of SWCT depends on environmental factors such as land use, saturated conductivity and storm size (Hessel and Tenge, 2008) or plot slope length (e.g. Gilley and Risse, 2000; Smets et al., 2008b,a) and plot slope gradient (e.g. Renard et al., 1997; Syversen, 2005). Nevertheless, very few quantitative assessments of the effects of these environmental factors on SWCT effectiveness in reducing R and SL have been made. Limited understanding of environmental effects on SWCT effectiveness in reducing $\mathrm{R}$ and SL also limits the incorporation of SWCT application in erosion models. (e.g. Hessel and Tenge, 2008). Finally, a comprehensive assessment of the effectiveness of SWCTs also needs to consider temporal aspects of SWCT application: the temporal variability in SWCT effectiveness and how this effectiveness evolves over the years since the initial application. The latter has been studied for the build-up of soil organic carbon (Hao et al., 2002), soil biochemical properties (Madejón et al., 2009) and crop yield (Rusinamhodzi et al., 2011; Van den Putte et al., 2010). However, no such study exists with respect to the long-term effects of SWCTs on R or SL.

An overview and meta-analysis of available field-measured data on the effectiveness of various SWCTs in reducing both $\mathrm{R}$ and SL can provide important additional insights and can improve our ability to model the effects of SWCT in reducing R and SL under various conditions. However, relatively few comprehensive overviews are currently available. A global assessment of SWCT effectiveness in reducing SL was made by Montgomery (2007b), but this analysis does not include $\mathrm{R}$ nor does it allow a quantification of the effectiveness of specific techniques. For Europe and the Mediterranean, available overviews of SWCTs effectiveness are very limited (Table 1) Several of the available overviews of erosion rates and their controlling factors do not consider SWCTs explicitly (Table 1). Furthermore, the reviews that consider SWCTs often do not include the effectiveness of SWCTs in reducing R. Studies that do consider R are limited to a few specific techniques (Table 1 ). 


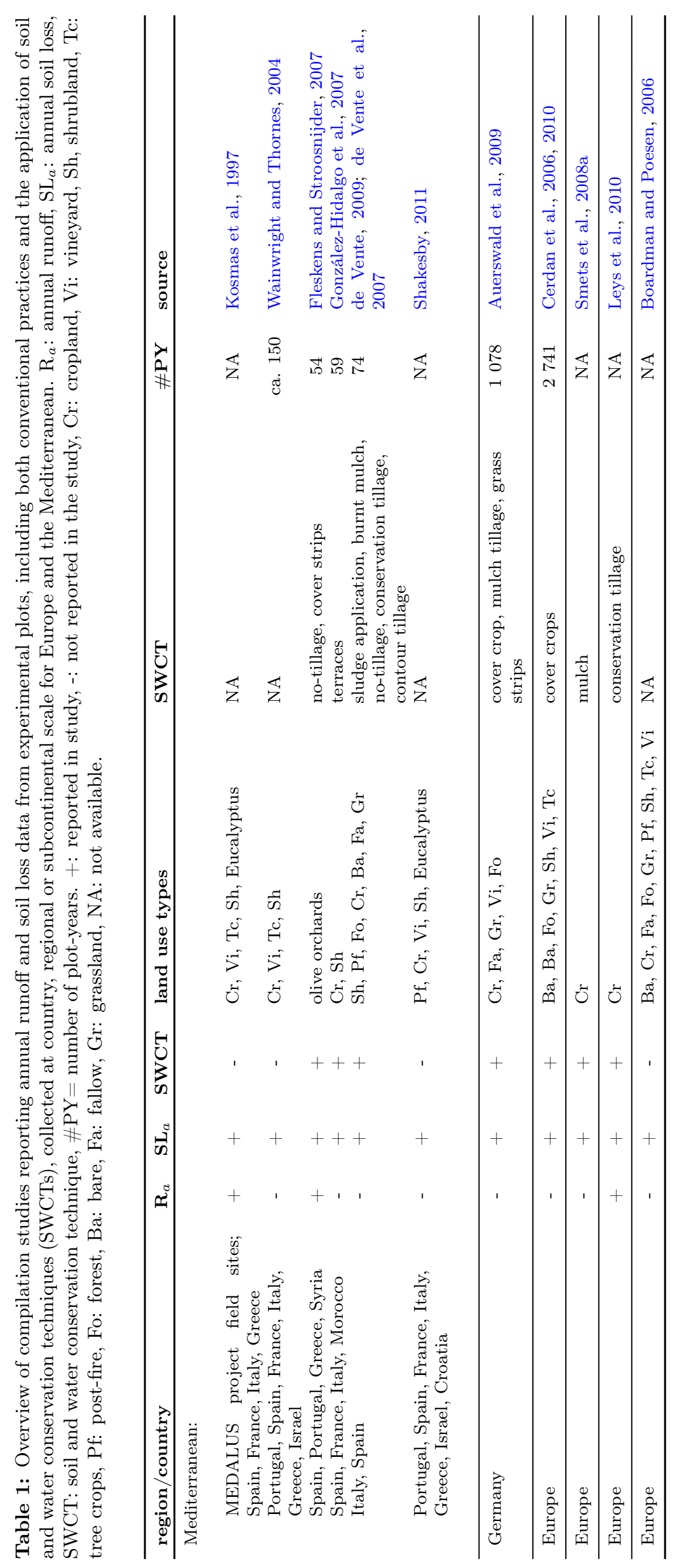


Therefore, the objectives of this paper are (1) to provide an overview of field plot data on effectiveness of SWCT in reducing annual runoff $\left(\mathrm{R}_{a}, \mathrm{~mm} \cdot \mathrm{yr}^{-1}\right)$ and annual soil loss $\left(\mathrm{SL}_{a}\right.$, $\mathrm{Mg} \cdot \mathrm{ha}^{-1} \cdot \mathrm{yr}^{-1}$ ) in Europe and the Mediterranean, (2) to quantify the effectiveness of different SWCT types in reducing both $\mathrm{R}_{a}$ and $\mathrm{SL}_{a}$ and to explore the effect of SWCTs on the relations between $\mathrm{R}_{a}$ and $\mathrm{SL}_{a}$ and (3) to explore the relations of SWCT effectiveness with some important variables that were reported in the experimental studies (i.e. magnitude of $\mathrm{R}_{a}$ and $\mathrm{SL}_{a}$, plot length, plot slope gradient, annual precipitation $\left(\mathrm{P}_{a}, \mathrm{~mm} \cdot \mathrm{yr}^{-1}\right)$, and the number of consecutive years of SWCT application).

\section{Data collection}

Annual runoff and soil loss data, measured on bounded plots where a SWCT was applied, for Europe and the Mediterranean were collected from research papers, books, project reports and $\mathrm{PhD}$. theses (Figure 1). Each plot represents a combination of a soil type, a plot length, a slope gradient, and a land use type and is associated with one type of SWCT (Table 2). SWCTs were classified into three groups according to Morgan (2005) (Table 2). Only runoff and soil loss measurements from bounded runoff plots under natural rainfall, with a minimum length of $5 \mathrm{~m}$ were retained. Only annual data are considered: either plot data were collected during at least a full year, or the reported data could be extrapolated to represent a full year with a sufficient degree of reliability, i.e. when measurements were conducted for at least $80 \%$ of the year and rainfall was uniformly distributed throughout the year (Maetens et al., 2012), or when authors indicated that the measurements were representative for a full year. For each plot, the corresponding number of plot-years (\#PY) was determined, whereby 1 PY corresponds to a measuring period of 1 year on a single runoff plot.

Table 2: List of soil and water conservation techniques (SWCTs) tested on runoff and soil loss plots in Europe and the Mediterranean. Ba: bare soil, Cr: cropland, Cs: construction sites, Fa: fallow, Fo: forest, Gr: grassland, Pf: post-fire, Sh: shrubland, Tc: tree crops, Vi: vineyard

\begin{tabular}{|c|c|c|}
\hline SWCT & & Description \\
\hline \multicolumn{3}{|c|}{ Crop and vegetation management } \\
\hline Cc: & cover crops & $\begin{array}{l}\text { cover crop during the intercropping season, established after harvest (e.g. Laloy and Bielders, } \\
2010 \text { ). }\end{array}$ \\
\hline $\mathrm{Mu}:$ & mulching & application of stone or organic mulch (crop residue or straw) (e.g. Brown, 1996). \\
\hline Bs: & buffer strips & $\begin{array}{l}\text { Strips of perennial vegetation (usually grasses) used to increase infiltration, slow down runoff } \\
\text { and increase sediment deposition(e.g. Uusi-Kämppä, 2005). }\end{array}$ \\
\hline Sc: & strip cropping & $\begin{array}{l}\text { drilling or planting in strips of alternating crop types (e.g. Köse et al., 1996; Köse and Taysun, } \\
2002 \text { ). }\end{array}$ \\
\hline Ex: & exclosure & $\begin{array}{l}\text { closing of areas for grazing and agriculture (e.g. Bruggeman et al., 2005; Masri et al., 2005; } \\
\text { Mazour, 1992). }\end{array}$ \\
\hline \multicolumn{3}{|r|}{ ( } \\
\hline $\mathrm{Nt}:$ & no-tillage & no tillage operations when the traditional practice is tillage (e.g. Turtola et al., 2007). \\
\hline Rt: & reduced tillage & $\begin{array}{l}\text { different forms of reduced tillage resulting in a smaller disturbance of the plough layer than } \\
\text { conventional cultivationKwaad et al. (1998). }\end{array}$ \\
\hline Ct: & contour tillage & tillage operations parallel the contour (e.g. Quinton and Catt, 2004). \\
\hline Dt: & deep tillage & deep non-inversion tillage to improve infiltration (e.g. Chomanicová, 1988; Suchanic, 1987). \\
\hline Dr: & drainage & application of subsurface drainage pipes (e.g. Øygarden, 1996; Øygarden et al., 1997) \\
\hline Sa: & soil amendment & $\begin{array}{l}\text { application of soil conditioners or fertilizer to improve soil soil structural stability: i.e. phos- } \\
\text { phogypsum (e.g. Agassi and Benhur, 1991), polymers(e.g. Chomanicová, 1988; Lopez-Bermudez } \\
\text { et al., 1991; Romero-Díaz et al., 1999), sewage sludge (e.g. Ingelmo et al., 1998) and NPK fer- } \\
\text { tilizer (e.g. Kroumov and Malinov, 1989). }\end{array}$ \\
\hline \multicolumn{3}{|c|}{ Mechanical methods } \\
\hline Te: & terraces & construction of earthen or stone terraces parallel the contour (e.g. Koulouri and Giourga, 2007). \\
\hline & contour bunds & stone or earthen bunds constructed parallel to the contour (e.g. Pinczés, 1982) \\
\hline Gt: & geotextile & $\begin{array}{l}\text { application of geotextile mats (e.g. Bhattacharyya et al., 2008, 2009; Jankauskas et al., 2008; } \\
\text { Mitchell et al., 2003). }\end{array}$ \\
\hline
\end{tabular}

Most plots were equipped with tanks for collecting runoff and soil loss. However, for a small number of plots $(\mathrm{n}=27)$, soil loss was determined by measuring rill volumes (Feiza et al., 2007; Jankauskas and Jankauskiene, 2003; Jankauskas et al., 2007). These volumetric measurements were converted to $\mathrm{SL}_{a}$ data (in $\mathrm{Mg} \cdot \mathrm{ha}^{-1} \cdot \mathrm{yr}^{-1}$ ) by assuming a soil bulk density of $1.5 \mathrm{~g} \cdot \mathrm{cm}^{-3}$ and 


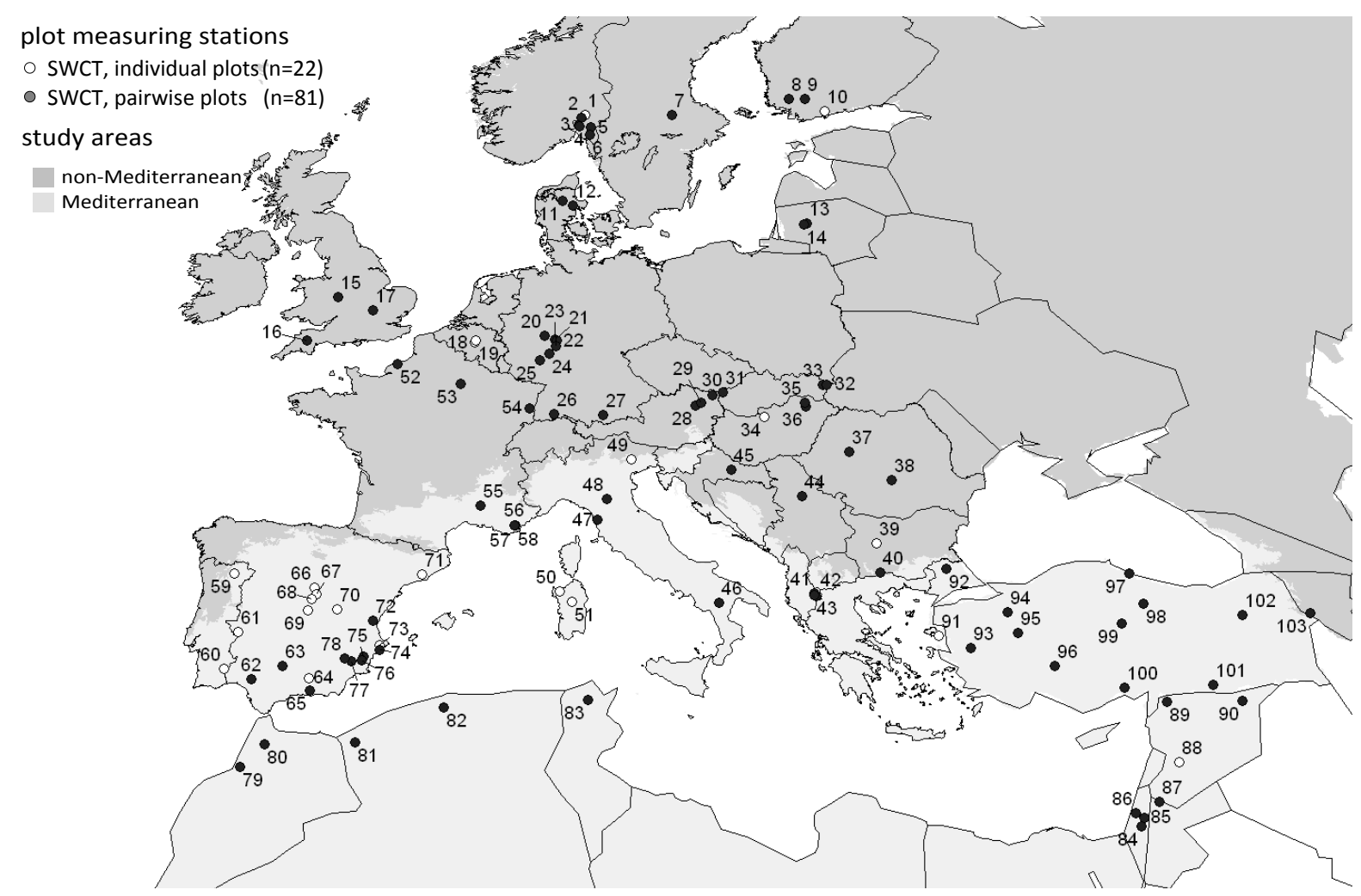

Figure 1: Geographical distribution of runoff and soil loss plot measuring stations included in the individual and paired plot SWCT databases for Europe and the Mediterranean. Black circles represent stations included in the paired plot database, while open circles represent stations which are only included in the individual plot database. The division between Mediterranean and Non-Mediterranean was derived from the LANMAP2 database (Mücher et al., 2010; Metzger et al., 2005). $\mathrm{n}=$ number of plot measuring stations.

by adding $25 \%$ to account for interrill erosion. This value was based on a literature review by Govers and Poesen (1988). If available, also the plot length, plot gradient, annual precipitation and measuring period were included in the data compilation.

\section{Characteristics of the collected plot data}

Figure 1 shows the SWCTs that have been tested in Europe and the Mediterranean. Relatively few plot data are available for Northern latitudes and for Eastern European countries compared to other regions. This may be partly explained by the fact that results from most plot studies in Eastern Europe are only reported in the local language and have not been published internationally. Nevertheless, this study represents the largest compilation of SWCT effectiveness measurements in Europe and the Mediterranean. An overview of the collected data per country is given in Table 3. Analyses of these data revealed no clear regional differences in the type of SWCTs evaluated (Table 3 ).

SWCTs have been tested on runoff plots in Europe and the Mediterranean since 1956 (Jung and Brechtel, 1980). Since then, the number of plots gradually increased and peaked between 1987 and 1997 (Figure 2a). This peak is considerably later than the majority of runoff plot measurements in the USA (between 1930 and 1942; Laflen and Moldenhauer, 2003) and the majority of catchment sediment yield studies in Europe (Vanmaercke et al., 2011b). The decline in the number of plots after 1997 is partly due to the termination of some large research projects (e.g. MEDALUS). Furthermore, recently collected plot data may not have been published yet. However, measuring runoff and soil loss from plots is labour- and cost-intensive and the decline 
Table 3: Overview of the different soil and water conservation techniques (SWCTs) included in the global plot database and publications from which annual runoff and soil loss data were extracted in each country in Europe and the Mediterranean. References followed by ${ }^{*}$ report data for plots where only SWCTs were applied, other references contain plots included in the paired plot database. References followed by ${ }^{T S}$ were used for the analysis of plot data time-series (consecutive years) of SWCT application. Numbers between brackets refer to the plot measuring stations indicated in Figure 1.

\begin{tabular}{|c|c|c|}
\hline Country & SWCT & Source \\
\hline Albania & $\begin{array}{l}\text { notillage } \\
\text { reduced tillage } \\
\text { drainage }\end{array}$ & $\begin{array}{l}\text { Grazhdani et al., } 1999 \text { [42] } \\
\text { Grazhdani et al., } 1999 \text { [42] } \\
\text { Grazhdani et al., } 1996 \text { [41-43]; Grazhdani, pers. comm. [41-43] }\end{array}$ \\
\hline Algeria & $\begin{array}{l}\text { cover crops } \\
\text { buffer strips } \\
\text { exclosure } \\
\text { notillage } \\
\text { contour tillage }\end{array}$ & $\begin{array}{l}\text { Arabi and Roose, } 1993[82] \\
\text { Arabi and Roose, } 1993[82] \\
\text { Mazour, } 1992[81] \text {; Morsli et al., } 2004[81] \\
\text { Arabi and Roose, } 1993[82] \\
\text { Mazour, } 1992[81] \text {; Mazour et al., } 2008^{T S}[81]\end{array}$ \\
\hline Austria & cover crops & Klik, 2003 [28-30]; Klik, 2010; Klik, pers. comm. \\
\hline Belgium & $\begin{array}{l}\text { cover crops } \\
\text { notillage } \\
\text { reduced tillage }\end{array}$ & $\begin{array}{l}\text { Laloy and Bielders, } 2008^{*} ; \text { Laloy and Bielders, } 2010^{*}[18,19] \\
\text { Laloy and Bielders, 2008*; Laloy and Bielders, } 2010^{*}[18,19] \\
\text { Laloy and Bielders, 2008*;Laloy and Bielders, 2010* }[18,19]\end{array}$ \\
\hline Bulgaria & $\begin{array}{l}\text { buffer strips } \\
\text { soil amendment }\end{array}$ & $\begin{array}{l}\text { Biolchev, 1975* [39]; Malinov, 1999* [39], cited by Rousseva et al., } 2006 \\
\text { Kroumov and Malinov, } 1989 \text { [40] }\end{array}$ \\
\hline Croatia & $\begin{array}{l}\text { notillage } \\
\text { contour tillage }\end{array}$ & $\begin{array}{l}\text { Basic et al., 2001, 2004 } \\
\text { Basic et al., 2001, } 2004^{T S}\end{array}$ \\
\hline Denmark & $\begin{array}{l}\text { cover crops } \\
\text { reduced tillage }\end{array}$ & $\begin{array}{l}\text { Schjønning et al., } 1995^{*}[11,12] \\
\text { Schjønning et al., } 1995^{*}[11,12]\end{array}$ \\
\hline Finland & $\begin{array}{l}\text { cover crops } \\
\text { buffer strips } \\
\text { notillage } \\
\text { reduced tillage } \\
\text { contour tillage } \\
\text { drainage }\end{array}$ & $\begin{array}{l}\text { Turtola et al., } 2007^{*}[9] \\
\text { Puustinen et al., 2005, } 2007 \text { [8]; Uusi-Kämppä, } 2005[9] \\
\text { Puustinen et al., 2005, } 2007 \text { [8]; Turtola et al., 2007 } 2007^{T S}[9] \\
\text { Puustinen et al., 2005, } 2007 \text { [8]; Turtola et al., } 2007^{T S}[9] \\
\text { Puustinen et al., 2005, } 2007 \text { [8] } \\
\text { Warsta et al., 2009* [10] }\end{array}$ \\
\hline France & $\begin{array}{l}\text { cover crops } \\
\text { mulching } \\
\text { buffer strips } \\
\text { notillage } \\
\text { reduced tillage }\end{array}$ & $\begin{array}{l}\text { Messer, } 1980 \text { [54]; Viguier, } 1993 \text { [56-58] } \\
\text { Ballif, } 1989 \text { [53]; Viguier, 1993 [56-58] } \\
\text { AREDVI, } 2003 \text { [55]; Le Bissonnais et al., 2004 [52] } \\
\text { Messer, } 1980 \text { [54]; Viguier, } 1993^{T S} \text { [56-58] } \\
\text { Ballif, } 1989 \text { [53] }\end{array}$ \\
\hline Germany & $\begin{array}{l}\text { cover crops } \\
\text { buffer strips } \\
\text { reduced tillage } \\
\text { contour tillage }\end{array}$ & $\begin{array}{l}\text { Emde, } 1992[25] ; \text { Jung and Brechtel, } 1980[20-23,26-27] \\
\text { Jung and Brechtel, } 1980^{*}[20-23,26-27] ; \text { Voss, } 1978[24] \\
\text { Jung and Brechtel, 1980* }[20-23,26-27] \\
\text { Jung and Brechtel, 1980* }[20-23,26-27]\end{array}$ \\
\hline Greece & terraces & Koulouri and Giourga, 2007* [91] \\
\hline Hungary & $\begin{array}{l}\text { contour tillage } \\
\text { contour bunds } \\
\text { geotextile }\end{array}$ & $\begin{array}{l}\text { Hudek and Rey, 2009* [34]; Pinczés, } 1982 \text { [36] } \\
\text { Pinczés, } 1982 \text { [36] } \\
\text { Kertesz et al., 2007 [35]; Kertesz, pers. comm. [35] }\end{array}$ \\
\hline Israel & soil amendment & Agassi and Benhur, 1991 [86]; Agassi et al., 1990 [86] \\
\hline Italy & $\begin{array}{l}\text { cover crops } \\
\text { mulching } \\
\text { notillage } \\
\text { reduced tillage } \\
\text { drainage } \\
\text { geotextile }\end{array}$ & $\begin{array}{l}\text { Bini et al., 2006* [49]; Caredda et al., 1997* [50] } \\
\text { Rivoira et al., 1989* [51] } \\
\text { Postiglione et al., 1990 [46] } \\
\text { Basso et al., 1983 }{ }^{T S} \text { [46]; Chisci and Zanchi, 1981* [47]; Chisci, } 1989 \text { [47,48]; Postiglione et al., } 1990 \text { [46] } \\
\text { Chisci and Zanchi, 1981 [47] } \\
\text { Zanchi, } 1983 \text { [48] }\end{array}$ \\
\hline Jordan & mulching & Abu-Zreig, 2006 [87]; Abu-Zreig et al., 2011 [87] \\
\hline Lithuania & $\begin{array}{l}\text { cover crops } \\
\text { notillage } \\
\text { reduced tillage } \\
\text { geotextile }\end{array}$ & $\begin{array}{l}\text { Jankauskas and Jankauskiene, } 2003^{*}[13] \text {; Jankauskas et al., 2007* [13] } \\
\text { Feiza et al., } 2007[13] \\
\text { Feiza et al., } 2007[13] \\
\text { Jankauskas et al., 2008 [14] }\end{array}$ \\
\hline Morocco & $\begin{array}{l}\text { reduced tillage } \\
\text { contour tillage }\end{array}$ & $\begin{array}{l}\text { Heusch, } 1970[80] \\
\text { Laouina et al., 2003 } \\
T S \\
{[79]}\end{array}$ \\
\hline Norway & $\begin{array}{l}\text { reduced tillage } \\
\text { drainage }\end{array}$ & $\begin{array}{l}\text { Børresen, pers. comm. [34]; Grønsten and Lundekvam, 2006 }{ }^{T S}[34] \text {; Lundekvam, } 2007^{T S}[2,5-6] \\
\text { Øygarden, } 1996 \text { [1]; Øygarden et al., } 1997^{*}[1]\end{array}$ \\
\hline $\begin{array}{l}\text { Palestinian } \\
\text { territories }\end{array}$ & terraces & Abu Hammad et al., 2004, 2006 [85]; Al-Seekh and Mohammad, 2009 [84] \\
\hline Portugal & $\begin{array}{l}\text { cover crops } \\
\text { notillage } \\
\text { contour tillage }\end{array}$ & $\begin{array}{l}\text { Roxo et al., 1996* [60] } \\
\text { Oliveira, 2005* [59] } \\
\text { Oliveira, 2005* [59] }\end{array}$ \\
\hline Romania & $\begin{array}{l}\text { notillage } \\
\text { reduced tillage } \\
\text { terraces }\end{array}$ & $\begin{array}{l}\text { Nistor and Ionita, } 2002[37] \\
\text { Nistor and Ionita, 2002 [37] } \\
\text { Teodorescu and Badescu, } 1988[38]\end{array}$ \\
\hline Serbia & terraces & Djorović, $1990[44]$ \\
\hline Slovakia & $\begin{array}{l}\text { mulching } \\
\text { notillage } \\
\text { reduced tillage } \\
\text { deep tillage } \\
\text { soil amendment }\end{array}$ & $\begin{array}{l}\text { Chomanicová, } 1988 \text { [33] } \\
\text { Fulajtár and Janský, 2001 [31] } \\
\text { Chomanicová, } 1988 \text { [33]; Suchanic, } 1987[32] \\
\text { Chomanicová, } 1988 \text { [33]; Suchanic, } 1987 \text { [32] } \\
\text { Chomanicová, } 1988 \text { [33] }\end{array}$ \\
\hline
\end{tabular}


Table 3 continued

\begin{tabular}{|c|c|c|}
\hline Country & SWCT & Source \\
\hline Spain & $\begin{array}{l}\text { cover crops } \\
\text { mulching } \\
\text { buffer strips } \\
\text { exclosure } \\
\text { reduced tillage } \\
\text { contour tillage } \\
\text { soil amendment } \\
\text { terraces }\end{array}$ & $\begin{array}{l}\text { Gómez et al., } 2009 \text { [62]; Schnabel et al., 2001* [61] } \\
\text { Albaladejo et al., 2000 [78]; Bautista et al., 1996 [74] } \\
\text { Aspizua, 2003* [64]; Francia Martínez et al., } 2006 \text { [65]; Gómez et al., } 2004 \text { [63]; Martinez Raya et al., } \\
2006^{*}[65] \\
\text { Castillo et al., } 1997 \text { [78]; Martinez-Mena et al., } 1999 \text { [76] } \\
\text { Bienes et al., 2006* [67-70]; Francia Martínez et al., 2006 [65]; Gómez et al., 2004 }{ }^{T S} \text { [63] } \\
\text { Schnabel et al., 2001* [61] } \\
\text { Ingelmo et al., 1998 [72]; Lopez-Bermudez et al., 1991 [77]; Romero-Díaz et al., } 1999 \text { [77] } \\
\text { Llovet et al., 2009* [73]; Llovet, pers. comm. [73]; Martínez-Casasnovas and Ramos, 2006* [71]; Ramos } \\
\text { and Martínez-Casasnovas, 2006, 2007 [71]; Sanchez et al., 1994 [75]; Williams et al., 1995* [66] }\end{array}$ \\
\hline Sweden & $\begin{array}{l}\text { cover crops } \\
\text { no-tillage } \\
\text { reduced tillage }\end{array}$ & $\begin{array}{l}\text { Ulén and Kalisky, } 2005[7] \\
\text { Ulén and Kalisky, 2005 [7] } \\
\text { Ulén and Kalisky, 2005 [7] }\end{array}$ \\
\hline $\begin{array}{l}\text { Syrian } \\
\text { Arab } \\
\text { Republic }\end{array}$ & $\begin{array}{l}\text { cover crops } \\
\text { exclosure } \\
\text { reduced tillage } \\
\text { terraces }\end{array}$ & $\begin{array}{l}\text { Bruggeman et al., } 2005[89] \text {; Masri et al., } 2005[89] ; \\
\text { Shinjo et al., 2000 [90] } \\
\text { Bruggeman et al., 2005 } \\
\text { Ali, 2007* [88] }\end{array}$ \\
\hline Tunisia & contour tillage & Kaabia, 1995 [83] \\
\hline Turkey & $\begin{array}{l}\text { strip cropping } \\
\text { contour tillage }\end{array}$ & $\begin{array}{l}\text { Köse and Taysun, } 2002 \text { [93]; Köse et al., } 1996[93] \text {; } \\
\text { Köse and Taysun, } 2002^{T S} \text { [93]; Köse et al., 1996 } \\
\text { comm. [92, [93]; Oguz et al., 2006 }{ }^{T S} \text { [92,94-103]; Oguz, pers. }\end{array}$ \\
\hline U.K. & $\begin{array}{l}\text { mulching } \\
\text { reduced tillage } \\
\text { contour tillage } \\
\text { geotextile }\end{array}$ & $\begin{array}{l}\text { Brown, } 1996[16] \\
\text { Brown, } 1996 \text { [16]; Quinton and Catt, } 2004 \text { [17] } \\
\text { Quinton and Catt, } 2004[17] \\
\text { Bhattacharyya et al., 2008, } 2009 \text { [15]; Mitchell et al., } 2003 \text { [15] }\end{array}$ \\
\hline
\end{tabular}

in plot data collection may also be linked to the substitution of field measurements studies by modelling studies. Nevertheless, interest in field-measured data on the effects of SWCTs remains high as shown by the increase of the number of publications in recent years. Recent publications also review and re-analyse plot data collected over long periods which were never published internationally (e.g. Rousseva et al., 2006).

Figure $2 \mathrm{~b}$ shows that, while soil management (i.e. mainly tillage) and mechanical methods have been studied continually respecitively since 1956 (Jung and Brechtel, 1980) and 1962 (Pinczés, 1982), crop and vegetation management methods have only been studied significantly since 1984. This most likely reflects changing attitudes towards sustainable agricultural practices. The increase in interest in the effects of mechanical methods since 1990 is reflected in an increase in research on the effects of terracing on $\mathrm{R}_{a}$ and $\mathrm{SL}_{a}$ in reforested land (Llovet et al., 2009; Sanchez et al., 1994; Williams et al., 1995), and to the use of (biological) geotextiles (Bhattacharyya et al., 2008, 2009; Jankauskas et al., 2008; Kertesz et al., 2007; Mitchell et al., 2003).

Figure 3 shows the frequency distribution of the number of plots (\#PL) and \#PY over different plot slope lengths, slope gradients and annual precipitation depth. Soil management techniques (i.e. mostly tillage techniques) were mainly tested on gentle slopes while mechanical methods have been tested on steeper slopes. The frequency distribution of plot slope lengths and slope gradients is similar to the distribution for plots where no SWCTs are applied (Maetens et al., 2012), and is likely determined by experimental preferences, as the modal plot length and slope gradient are close to the standard (R)USLE plot which has a plot length of $22.13 \mathrm{~m}$ and a slope gradient of 9\% (Renard et al., 1997). The concentration of plot lengths and slope gradients around these values also implies that effects of plot length and slope gradient on SWCT effectiveness in reducing $\mathrm{R}_{a}$ and $\mathrm{SL}_{a}$ are difficult to assess for longer and steeper slopes.

Other important environmental data (e.g. soil characteristics such as texture, organic matter content) and climatological data (precipitation distribution and intensity) were not reported systematically in the reviewed literature and no global analysis of these variables was possible. Furthermore, \#PL for some of the studied SWCTs is limited, so no further division is made according to land use types (e.g. cropland, tree crops, vineyards) as this would reduce the plot sample size. These data limitations imply that there is likely a large variability in $\mathrm{R}_{a}$ and 

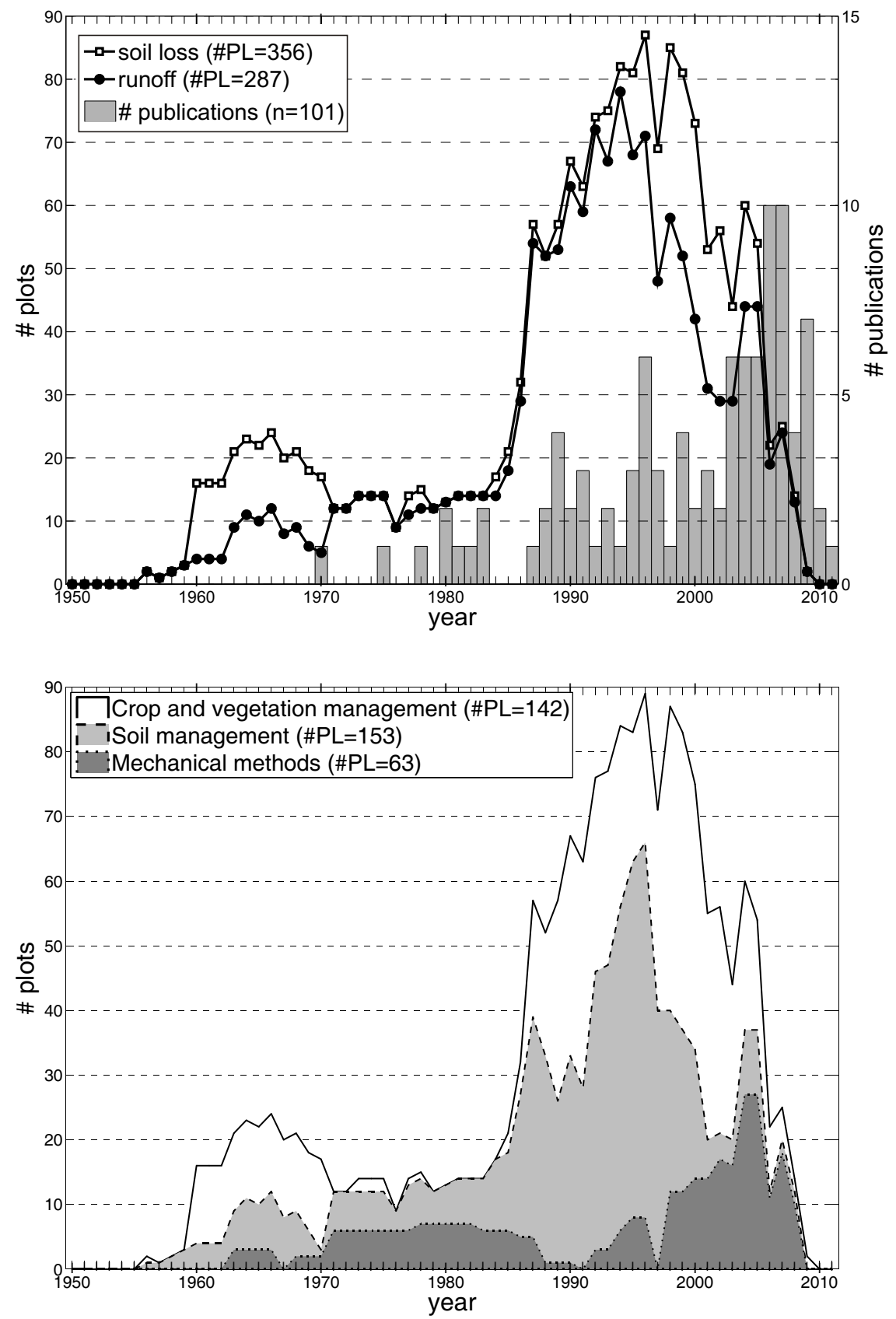

Figure 2: (a) Per-year evolution of the total number of erosion plots (\# plots) set up to test soil and water conservation techniques (SWCTs) for which annual runoff and soil loss were recorded based on the individual plot (IP) database for Europe and the Mediterranean (Table 3). Grey bars represent the total number of publications (\# publications) per publication year from which runoff and/or soil loss data were extracted. (b) Evolution of \# plots per year for which annual soil loss and runoff were recorded on plots with a SWCT based on the IP database. The full black line indicates the total \# plots, while dashed lines and grey tones indicate the relative proportions of the three major SWCT groups (Table 2). $\mathrm{n}=$ number of publications, \#PL $=$ number of plots. 

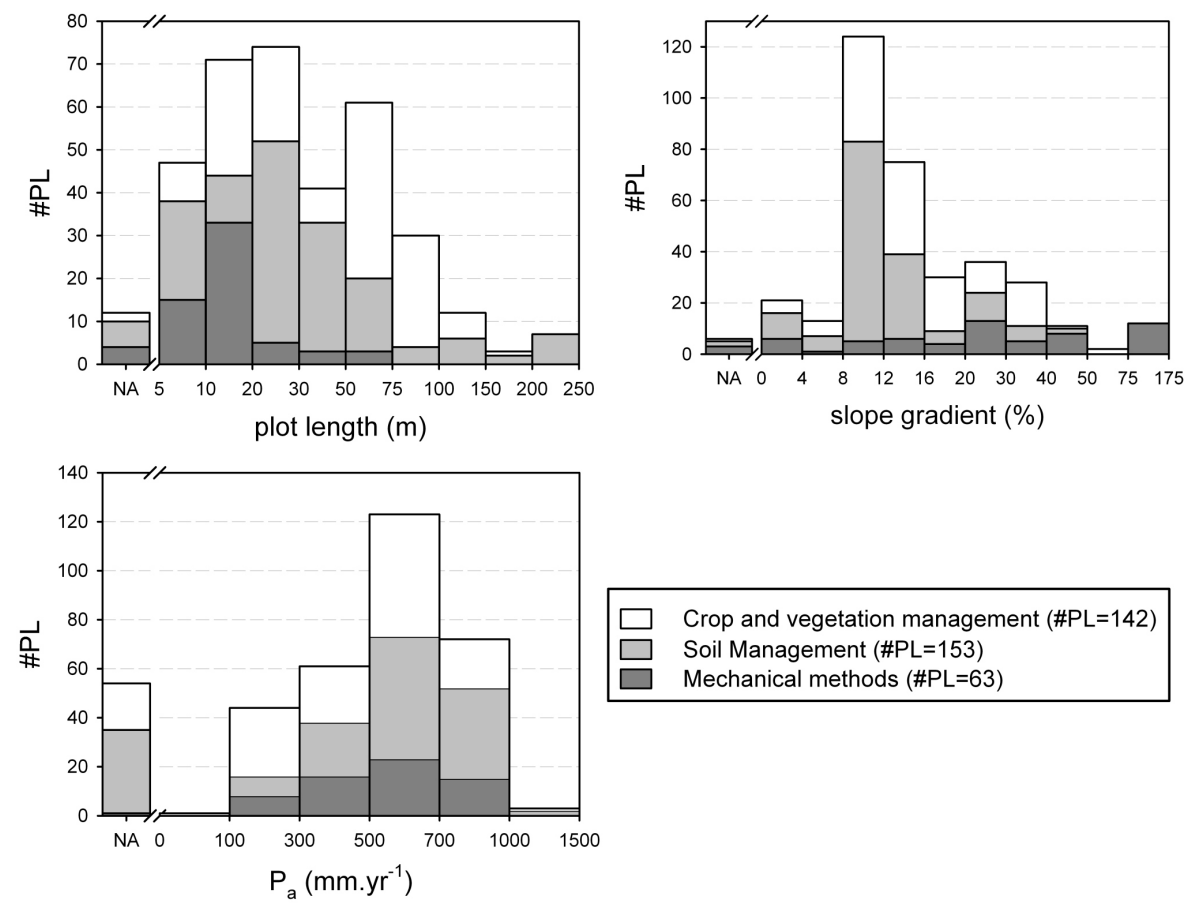

Figure 3: Frequency distribution of the number of plots (\# PL) included in the individual plot database for Europe and the Mediterranean for which annual runoff and/or soil loss data are available as a function of: (a) plot length, (b) slope gradient and (c) annual precipitation depth $\left(\mathrm{P}_{a}\right)$. A distinction is made between the three major SWCT groups (Table 2). \#PL: number of plots. NA: not available, i.e. plot length,slope gradient or Pa were not reported.

$\mathrm{SL}_{a}$ which can not be explained with the environmental data currently available, and any observed trends should be interpreted with care, considering possible effects of these unknown factors.

\section{Effectiveness of SWCTs in reducing annual runoff and soil loss}

In order to obtain a general overview of the effects of SWCT, the frequency distributions of annual runoff coefficient $\left(\mathrm{RC}_{a}, \%\right)$ and $\mathrm{SL}_{a}$, from all plots where SWCTs were applied were compared to frequency distributions of $\mathrm{RC}_{a}$ and $\mathrm{SL}_{a}$ measured on plots where local conventional land management practices were applied (Figure 4). The latter were derived from a previously established erosion plot database (Maetens et al., 2012). This approach allows a broad assessment of the overall effects of SWCTs on $\mathrm{RC}_{a}$ and $\mathrm{SL}_{a}$, but cannot be used to quantify the effectiveness of individual SWCTs. Therefore, all plots with SWCTs for which a paired plot under local conventional management existed (i.e. a plot on the same measuring site with the same characteristics but with application of the local conventional management instead of a SWCT) were selected from the full SWCT plot database (individual plot database, IP) and grouped together in a separate subset (paired plot database, PP).

\subsection{Overall effectiveness of SWCTs}

Fig. 4a does not show a clear effect of the application of SWCTs on the exceedance probability distribution of $\mathrm{RC}_{a}$. While $\mathrm{RC}_{a}$-values for plots with a (semi-)natural vegetation cover are clearly smaller than $\mathrm{RC}_{a}$-values for bare plots or plots under conventional cropland practices, 

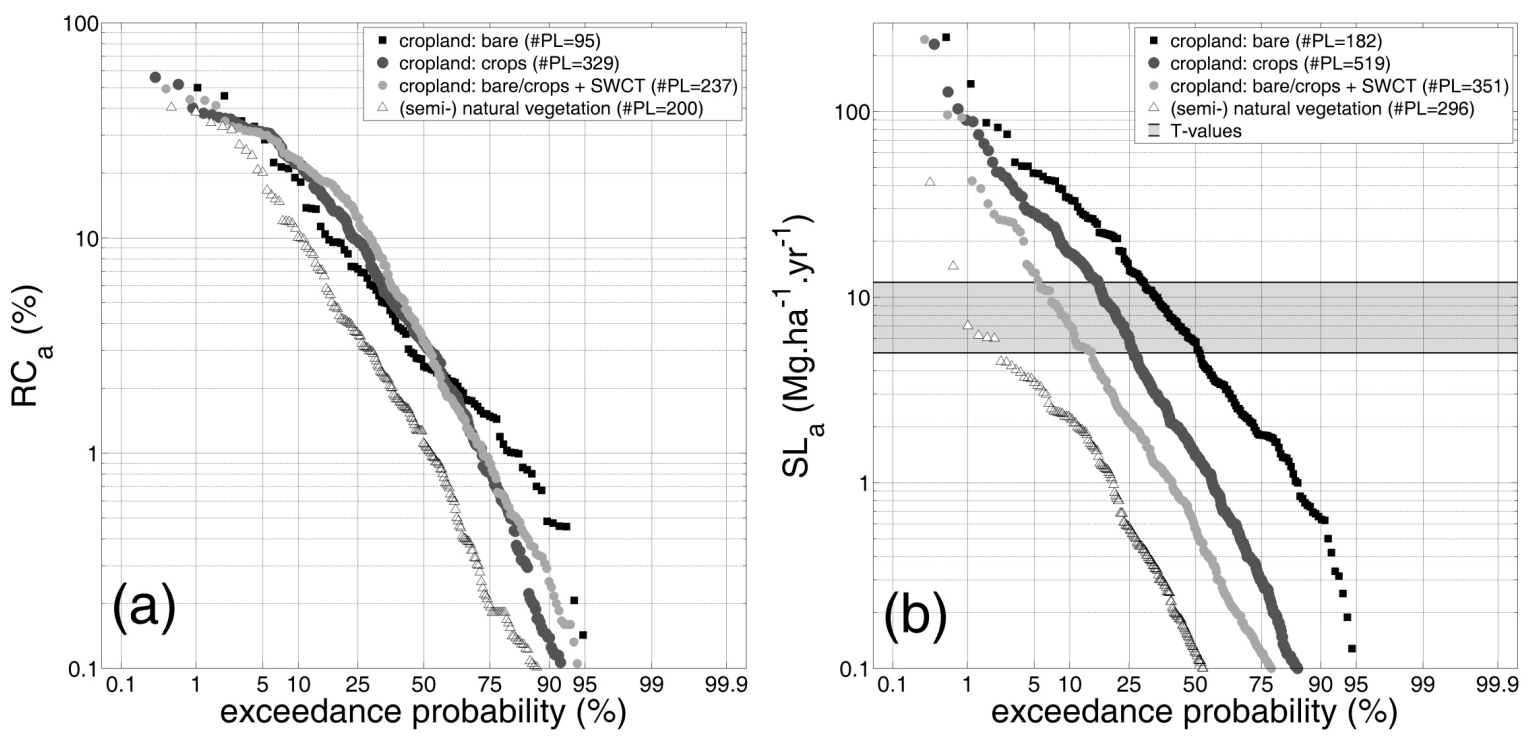

Figure 4: Exceedance probability distributions of (a) annual runoff coefficients $\left(\mathrm{RC}_{a}\right)$ and (b) annual soil loss $\left(\mathrm{SL}_{a}\right)$ for bare plots, cropland plots (annual crops, olive orchards and vineyards) without soil and water conservation techniques (SWCTs), plots on land with semi-natural vegetation (forest, shrubland and grassland; obtained from the plot runoff and soil loss database described in (Maetens et al., 2012), and all cropland plots with SWCT application (this study, Table 3). For $\mathrm{SL}_{a}$, the range of tolerable soil losses (T-values, i.e. 5-12 $\mathrm{Mg} \cdot \mathrm{ha}^{-1} \cdot \mathrm{yr}^{-1}$ ) as defined by (Montgomery, 2007b) is indicated in grey. \#PL: number of plots.

this difference in $\mathrm{RC}_{a}$ is not observed for cropland plots where a SWCT was applied. On the other hand, Figure $4 \mathrm{~b}$ shows that the presence of a crop on the land already substantially reduces the exceedance probability of any given $\mathrm{SL}_{a}$ rate compared to the exceedance probability for $\mathrm{SL}_{a}$ from bare plots, while the application of SWCTs reduces the exceedance probability even further.

The observed exceedance probabilities correspond to the trend observed by Montgomery (2007) in a worldwide study of $\mathrm{SL}_{a}$ rates. Nevertheless, the reduction of the exceedance probability of any given $\mathrm{SL}_{a}$ rate by the application of SWCTs is generally smaller in Europe and the Mediterranean (Figure 4b) than the reduction observed by Montgomery (2007). The latter report that the exceedance probability of a soil loss tolerance level (T-value) of $5 \mathrm{Mg} \cdot \mathrm{ha}^{-1} \cdot \mathrm{yr}^{-1}$ drops by $75 \%$ when SWCTs are applied, compared to $\mathrm{SL}_{a}$ rates on cropland without SWCTs (Table 3). However, for Europe and the Mediterranean (this study) a reduction of only $14 \%$ is observed (Table 3). The larger effect of SWCT application on $\mathrm{SL}_{a}$ rates in the global study (Montgomery, $2007 \mathrm{~b}$ ) is due to the fact that $\mathrm{SL}_{a}$ rates on cropland reported by Montgomery (2007b) are generally much larger than those observed in this study (Table 3). These larger $\mathrm{SL}_{a}$ rates may be attributed to the inclusion of more erosion-prone sites in the global study (Montgomery, 2007b) as compared to the erosion plot sites in Europe and the Mediterranean (this study). In addition, the reported $\mathrm{SL}_{a}$ rates from land where SWCTs were applied are in general somewhat smaller in the global study by Montgomery (2007b) than in this study (Table 3). This difference may be attributed to the comparatively smaller number of plots where SWCTs were applied in the study by Montgomery (2007b), and thus the lower probability of observing extreme $\mathrm{SL}_{a}$ rates in that study. 
Table 3: Exceedance probabilities of annual soil loss on cropland without SWCTs and cropland with SWCTs for the worldwide study by Montgomery (2007b) and for Europe and the Mediterranean (this study), corresponding to two soil loss tolerance values (T). NA: not applicable(see also Figure 4).

\begin{tabular}{|c|c|c|c|c|}
\hline & \multicolumn{2}{|c|}{$\mathrm{T}=5 \mathrm{Mg} \cdot \mathrm{ha}^{-1} \cdot \mathrm{yr}^{-1}$} & \multicolumn{2}{|c|}{$\mathrm{T}=12 \mathrm{Mg} \cdot \mathrm{ha}^{-1} \cdot \mathrm{yr}^{-1}$} \\
\hline & World & $\begin{array}{l}\text { Europe and the } \\
\text { Mediterranean }\end{array}$ & World & $\begin{array}{l}\text { Europe and the } \\
\text { Mediterranean }\end{array}$ \\
\hline & (Montgomery, 2007b) & (this study) & (Montgomery, 2007b) & (this study) \\
\hline cropland without SWCT & $85 \%$ & $27 \%$ & $62 \%$ & $16 \%$ \\
\hline cropland with SWCT & $10 \%$ & $13 \%$ & NA & $4 \%$ \\
\hline difference & $75 \%$ & $14 \%$ & NA & $12 \%$ \\
\hline
\end{tabular}

\subsection{Effectiveness per technique}

To quantify the effectiveness of specific SWCTs, runoff ratios (RR) and soil loss ratios (SLR) were calculated for all paired plots (PP) in the database.

$$
\begin{aligned}
& R R=\frac{R_{a S W C T}}{R_{a C O N V}} \\
& S L R=\frac{S L_{a S W C T}}{S L_{a C O N V}}
\end{aligned}
$$

where:

$\mathrm{R}_{a S W C T}=$ annual runoff $\left(\mathrm{mm} \cdot \mathrm{yr}^{-1}\right)$ measured on the plot with SWCT.

$\mathrm{R}_{a C O N V}=$ annual runoff $\left(\mathrm{mm} \cdot \mathrm{yr}^{-1}\right)$ measured on the plot with conventional practice.

$\mathrm{SL}_{a S W C T}=$ annual soil loss $\left(\mathrm{Mg} \cdot \mathrm{ha}^{-1} \cdot \mathrm{yr}^{-1}\right)$ measured on the plot with SWCT.

$\mathrm{SL}_{a C O N V}=$ annual soil loss $\left(\mathrm{Mg}_{\mathrm{h}} \mathrm{ha}^{-1} \cdot \mathrm{yr}^{-1}\right)$ measured on the plot with conventional practice.

Except for deep tillage and terraces, the median effectiveness of all other SWCTs in reducing $\mathrm{R}_{a}$ is much smaller than for $\mathrm{SL}_{a}$ (Figure 5). Deep tillage is a technique aimed mainly at reducing runoff through increasing infiltration capacity (Chomanicová, 1988; Suchanic, 1987). For terraces, the higher median effectiveness in reducing $\mathrm{R}_{a}$ is explained by the fact that the terraces were established as water harvesting technique in an arid climate (Al-Seekh and Mohammad, 2009). The ranking of effectiveness for the individual SWCTs is different for $\mathrm{R}_{a}$ and $\mathrm{SL}_{a}$ reduction. Nevertheless, mechanical methods and crop and vegetation methods are generally more effective in reducing both $\mathrm{R}_{a}$ and $\mathrm{SL}_{a}$ than soil management methods. Exceptions to this trend are exclosures and strip cropping, which are less effective than the other SWCTs in the crop and vegetation management group. The relative order of SWCTs in terms of RR and SLR, underlines the large effectiveness of vegetation cover (cover crops, buffer strips), soil contact cover (mulching, geotextiles), or physical barriers (terraces, contour bunds) to reduce $\mathrm{R}_{a}$ and $\mathrm{SL}_{a}$. While tillage methods are less effective in reducing $\mathrm{R}_{a}$ and $\mathrm{SL}_{a}$ than crop and vegetation management or mechanical methods, they may be better suited where competition for water is an issue (Unger and Vigil, 1998) or mechanical methods are not compatible with agricultural practices (e.g. when mechanized tillage would be obstructed by terraces or stone bunds). Comparing the total \#PL for individual SWCTs with the median effectiveness of these techniques (Figure 6) also shows that larger efforts have been made for the assessment of the effectiveness of no-tillage, reduced tillage and contour tillage. However, these are generally not the most effective SWCTs (Figure 5). The limited \#PL for the more effective SWCTs also limits the range of environmental conditions where these more promising SWCTs have been tested in Europe and the Mediterranean.

Weigthed mean RR and SLR values were calculated for each SWCT (Table 4). In accordance with the central limit theorem (Maetens et al., 2012; Tijms, 2004), means were calculated by 

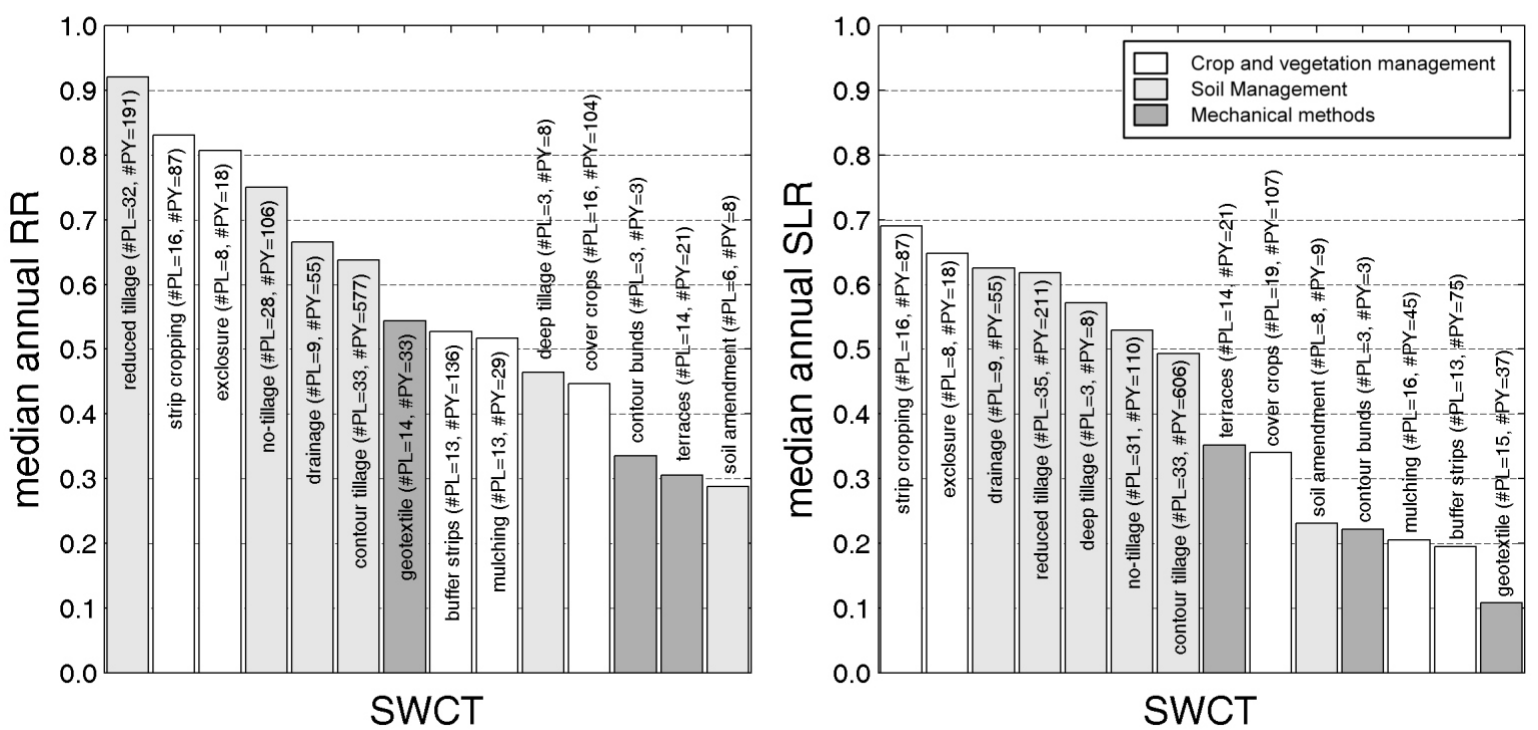

Figure 5: Median annual runoff ratios (RR, Eq. 1) and soil loss ratios (SLR, Eq. 2) for different soil and water conservation techniques (SWCTs) included in the paired plot database. SWCTs are ranked from left to right in order of increasing effectiveness. \#PL: number of plots, \#PY: number of plot-years.
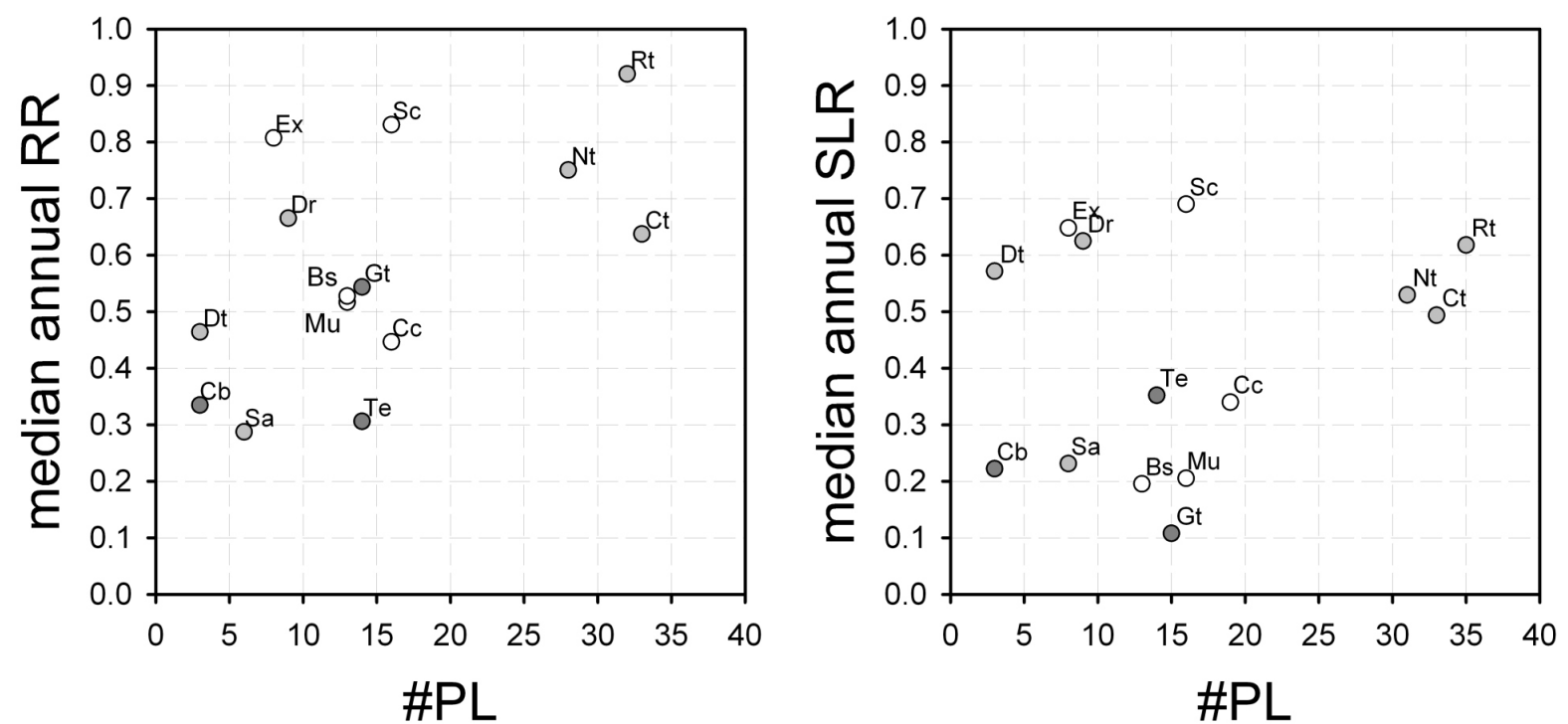

\begin{tabular}{|llll|}
\hline $\mathrm{O}$ & $\begin{array}{l}\text { crop and vegetation } \\
\text { management }\end{array}$ & $\mathrm{O}$ & $\begin{array}{l}\text { mechanical } \\
\text { management } \\
\text { methods }\end{array}$ \\
$\mathrm{Cc}:$ cover crops & $\mathrm{Nt}:$ no-tillage & $\mathrm{Te}$ : terraces \\
$\mathrm{Mu}:$ mulching & $\mathrm{Rt}$ reduced tillage & $\mathrm{Cb}$ : contour bunds \\
$\mathrm{Bs}:$ buffer strips & $\mathrm{Ct}$ contour tillage & $\mathrm{Gt}$ geotextile \\
$\mathrm{Sc}:$ strip cropping & $\mathrm{Dt}$ deep tillage & \\
$\mathrm{Ex}:$ exclosure & $\mathrm{Dr}:$ drainage & \\
& $\mathrm{Sa}:$ soil amendment & \\
\hline
\end{tabular}

Figure 6: Median annual runoff ratio (RR, Eq. 1) and annual soil loss ratio (SLR, Eq. 2) for different SWCTs versus the number of plots (\#PL) used to test the corresponding SWCT. 
weighting the RR and SLR for each paired plot by the square root of the \#PY. Figure 7 shows the weighted mean and distribution of SLR and RR for each SWCT. This figure illustrates that the range of SLR and RR for a given technique can be very large, indicating an important effect of local environmental and experimental conditions. Hence, the mean and median reduction ratios for a specific SWCT should be interpreted with caution as they may be subject to important variability. Furthermore, the frequency distributions of the reduction ratios are positively skewed, with a limited number of high RR and SLR values strongly affecting the weighted mean values (Figure 7). Nevertheless, both the median and weighted mean values show a similar pattern: most SWCTs are less effective in reducing runoff than in reducing soil loss.

Table 4: Number of plots (\#PL), number of plot-years (\#PY), weighted mean, median and coefficient of variation $(\mathrm{CV})$ for annual runoff ratios (RR) and annual soil loss ratios (SLR) per soil and water conservation technique (SWCT) for all data in the paired plot database. Weighting for the mean is done according to square root of the number of plot-years. * Drainage: all reported results refer to surface $\mathrm{R}_{a}$ and $\mathrm{SL}_{a}$ only, hence not to runoff and soil loss measured from the pipe outflow.

\begin{tabular}{|c|c|c|c|c|c|c|c|c|c|c|}
\hline \multirow{2}{*}{$\frac{\text { SWCT }}{\text { Crop and vegetation management }}$} & \multicolumn{5}{|c|}{$\mathbf{R R}$} & \multicolumn{4}{|c|}{ SLR } & CV \\
\hline & 16 & 104 & 1.21 & 0.45 & 1.31 & 19 & 107 & 0.49 & 0.34 & 0.84 \\
\hline mulching & 13 & 29 & 0.56 & 0.52 & 0.71 & 16 & 45 & 0.21 & 0.21 & 1.41 \\
\hline buffer strips & 13 & 136 & 0.63 & 0.53 & 0.83 & 13 & 75 & 0.26 & 0.20 & 1.02 \\
\hline strip cropping & 16 & 87 & 1.36 & 0.83 & 1.42 & 16 & 87 & 1.48 & 0.69 & 0.95 \\
\hline \multicolumn{11}{|l|}{ Soil management } \\
\hline no-tillage & 28 & 106 & 0.87 & 0.75 & 0.78 & 31 & 110 & 0.72 & 0.53 & 1.00 \\
\hline reduced tillage & 32 & 191 & 1.38 & 0.92 & 0.93 & 35 & 211 & 0.98 & 0.62 & 1.44 \\
\hline contour tillage & 33 & 577 & 0.69 & 0.64 & 0.96 & 33 & 606 & 0.50 & 0.49 & 1.41 \\
\hline deep tillage & 3 & 8 & 0.46 & 0.46 & 0.47 & 3 & 8 & 0.64 & 0.57 & 0.22 \\
\hline \multicolumn{11}{|l|}{ Mechanical methods } \\
\hline contour bunds & 3 & 3 & 0.39 & 0.33 & 0.76 & 3 & 3 & 0.33 & 0.22 & 1.15 \\
\hline geotextile & 14 & 33 & 0.71 & 0.54 & 0.84 & 15 & 37 & 0.16 & 0.11 & 1.62 \\
\hline
\end{tabular}



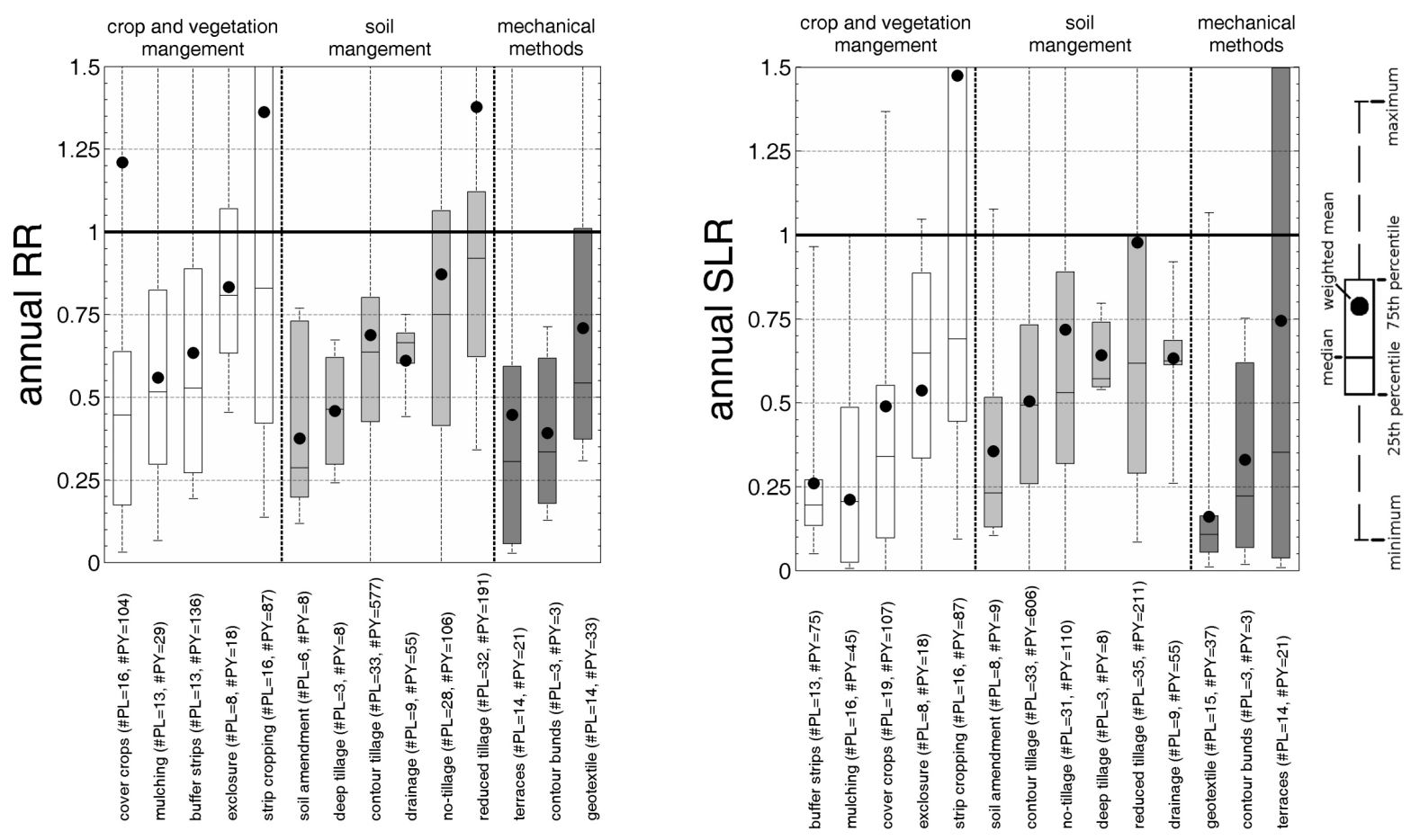

Figure 7: Frequency distribution and mean annual runoff ratio (RR, Eq. 1) and annual soil loss ratio (SLR, Eq. 2) for different soil and water conservation techniques (SWCTs) included in the paired plot database. SWCTs are ranked according to increasing median RR and SLR, within each of the 3 major SWCT groups (Table 2). \#PL: number of plots, \#PY: number of plot-years.

Relations between RR and SLR are given in Figure 8. Regarding crop en vegetation management techniques, mulching and buffer strips are generally more effective in reducing $\mathrm{SL}_{a}$ than cover crops, but the latter are slightly more effective in reducing $\mathrm{R}_{a}$ (Figure 8 ). With respect to tillage techniques, deep tillage seems less effective in reducing $\mathrm{SL}_{a}$ than contour tillage and no-tillage, but more effective in reducing $\mathrm{R}_{a}$. For some plots where no-tillage or reduced tillage was applied, a reduction in $\mathrm{SL}_{a}$ but an increase in $\mathrm{R}_{a}$ was measured. This is probably due to increased soil sealing which reduces soil loss but limits infiltration and increases $\mathrm{R}_{a}$. In these cases, soil conservation techniques are not necessarily soil and water conservation techniques. Hence, whether a SWCT reduces mainly $\mathrm{R}_{a}, \mathrm{SL}_{a}$ or both is an important factor to consider when selecting the most suitable SWCT to address degradation problems on a specific site. 


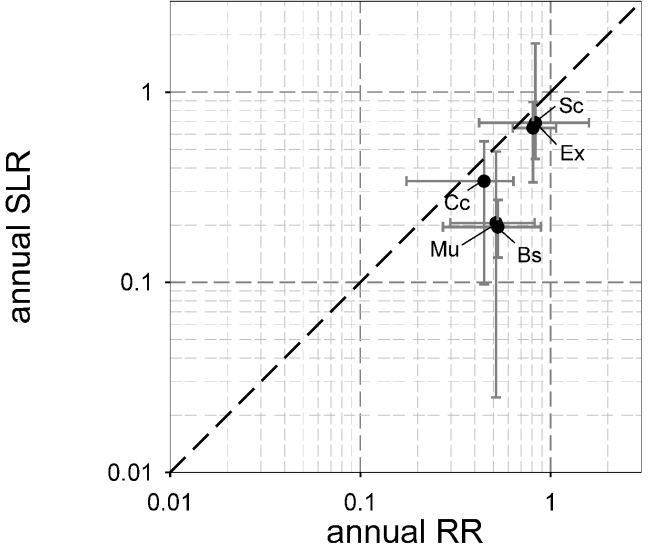

soil management

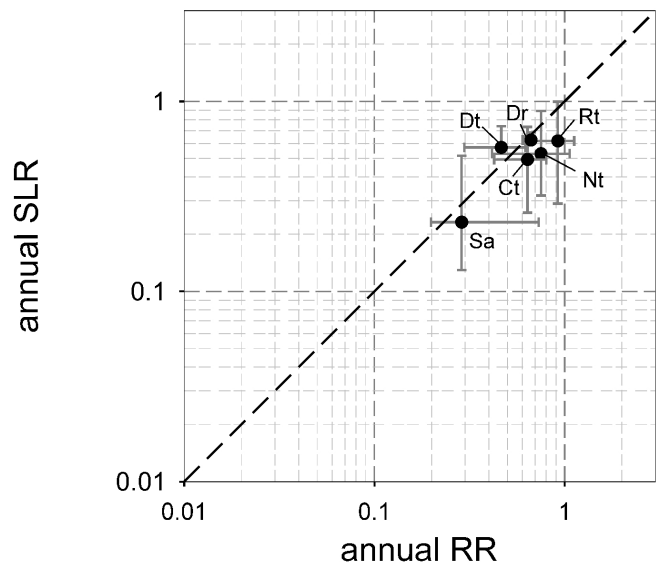

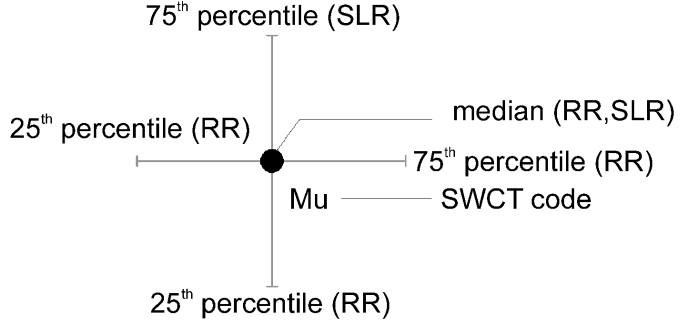

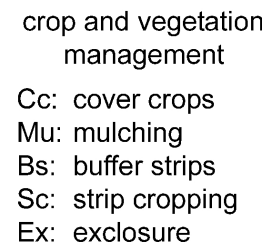

Ex: exclosure

\section{mechanical} methods

$\mathrm{Nt}$ : no-tillage

Rt: reduced tillage

Ct: contour tillage

Dt: deep tillage

Dr: drainage

Sa: soil amendment
Te: terraces

$\mathrm{Cb}$ : contour bunds

Gt: geotextile

\section{mechanical methods}

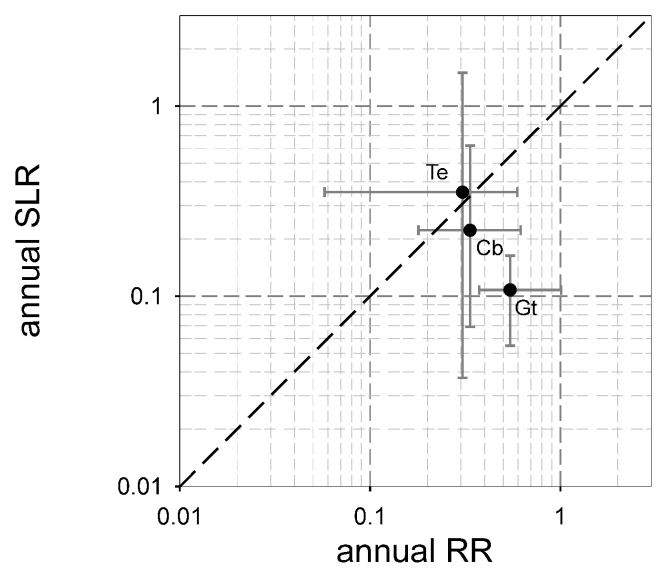

Figure 8: Relation between annual runoff ratio (RR, Eq. 1) and annual soil loss ratio (SLR, Eq. 2) for different soil and water conservation techniques (SWCTs) in the paired SWCT plot database. SWCTs plotting below the 1:1 line indicate soil loss reduction is stronger than runoff reduction.

\section{$5 \quad$ Factors controlling the effectiveness of SWCTs}

The large variability of RR and SLR values for individual SWCTs (Figure 7) prompts an analysis of the effect of environmental and experimental variables on the effectiveness of SWCTs. Due to a lack of data, this analysis was restricted to the variables reported in almost all publications from which data were extracted (Table 3): i.e. $\mathrm{RC}_{a}$ and $\mathrm{SL}_{a}$ from the reference plot, plot slope length, slope gradient and annual precipitation depth. $\mathrm{R}_{a}$ and $\mathrm{SL}_{a}$ are known to be strongly affected by soil characteristics (e.g. Bradford et al., 1987; Torri et al., 1997) as well as by rainfall distribution and intensity (e.g. Nearing et al., 2005). These factors may hence also affect SWCT effectiveness. However, these characteristics were insufficiently reported to allow a global analysis. 

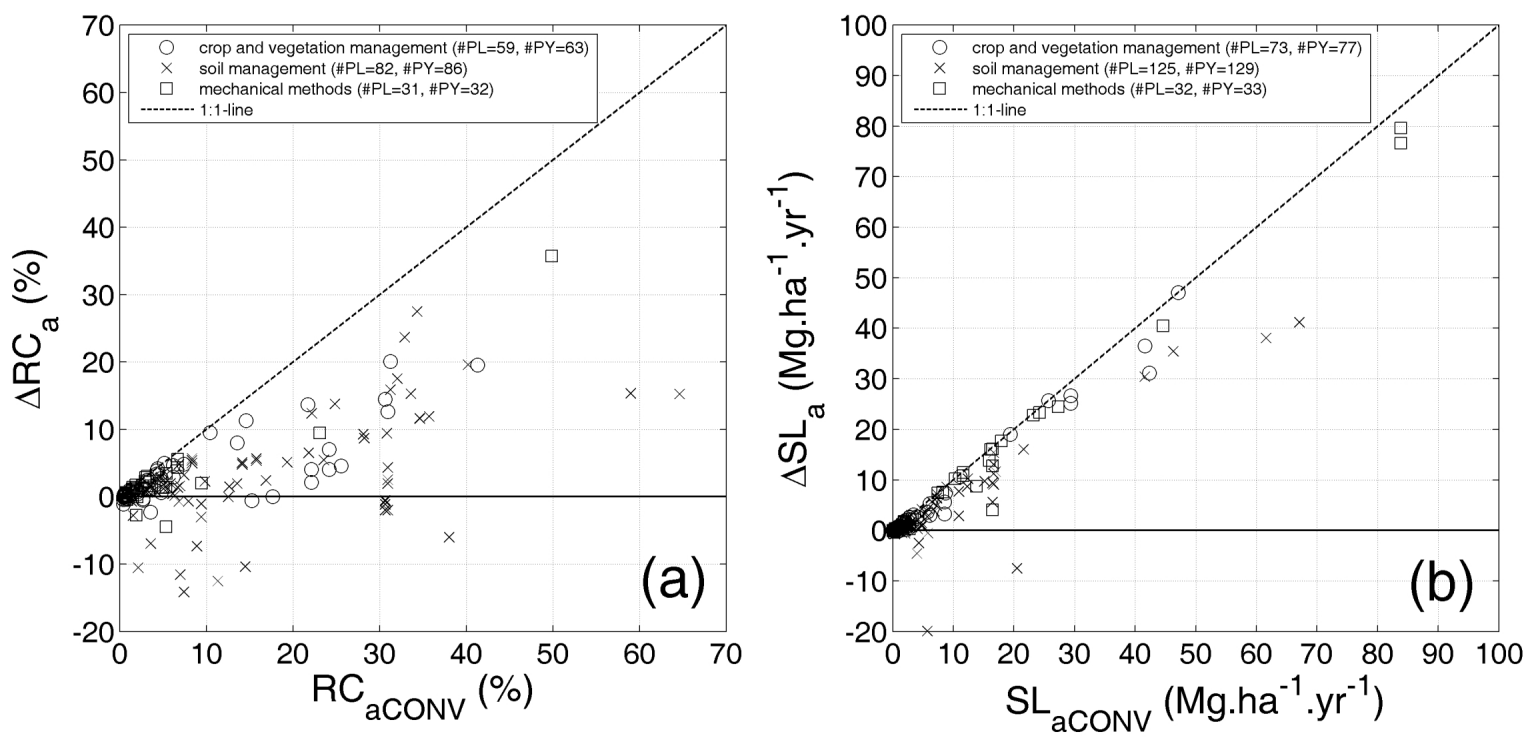

Figure 9: (a) Relation between the magnitude of annual runoff coefficients $\left(\mathrm{RC}_{a C O N V}\right)$ measured on plots without soil and water conservation techniques (SWCTs) and the absolute reduction of annual runoff coefficients $\left(\triangle \mathrm{RC}_{a}\right.$, Eq. 3) after applying a SWCT. (b) Relation between the magnitude of annual soil loss $\left(\mathrm{SL}_{a} C O N V\right)$, measured on plots without SWCTs, and the absolute reduction of annual soil loss $\left(\Delta \mathrm{SL}_{a}, \mathrm{Eq} .4\right)$ after applying a SWCT. \#PL: number of plots, \#PY: number of plot-years.

The effects of the $\mathrm{RC}_{a}$ and $\mathrm{SL}_{a}$ on the reference plot were investigated by calculating the absolute reduction of $\mathrm{RC}_{a}\left(\Delta \mathrm{RC}_{a}, \%\right)$ and $\mathrm{SL}_{a}\left(\Delta \mathrm{SL}_{a}, \mathrm{Mg} \cdot \mathrm{ha}^{-1} \cdot \mathrm{yr}^{-1}\right)$ :

$$
\begin{aligned}
& \Delta R C_{a}=R C_{a C O N V}-R C a_{a S W C T} \\
& \Delta S L_{a}=S L_{a C O N V}-S L a_{a S W C T}
\end{aligned}
$$

where:

$\mathrm{RC}_{a S W C T}=$ annual runoff coefficient $(\%)$ measured on the plot with SWCT.

$\mathrm{RC}_{a C O N V}=$ annual runoff coefficient (\%) measured on the plot with conventional practice.

Figure 9 shows that negative absolute reductions in $\mathrm{SL}_{a}$ and $\mathrm{RC}_{a}$ due to the application of SWCTs occur almost exclusively on plots where the $\mathrm{RC}_{a}$ and $\mathrm{SL}_{a}$ rates on the conventional plot are low. For $\mathrm{RC}_{a}$, these observations generally occur at $\mathrm{RC}_{a C O N V}$ rates below $20 \%$. For $\mathrm{SL}_{a}$, most negative $\triangle \mathrm{SL}_{a}$-values occur for $\mathrm{SL}_{a C O N V}$ rates below $2 \mathrm{Mg} \cdot \mathrm{ha}^{-1} \cdot \mathrm{yr}^{-1}$. This is attributed to the large variability in $\mathrm{SL}_{a}$ and $\mathrm{R}_{a}$ intrinsic to plot studies (e.g. Nearing et al., 1999) when the absolute $\mathrm{RC}_{a}$ and $\mathrm{SL}_{a}$ rates are low. As a result, the estimated low effectiveness of $\mathrm{SW}$ CTs for low absolute $\mathrm{RC}_{a}$ and $\mathrm{SL}_{a}$ values may be partly caused by the natural variability of of $\mathrm{R}_{a}$ and $\mathrm{SL}_{a}$ plot studies. Nevertheless, some negative $\Delta \mathrm{RC}_{a}$ values were also observed for higher $\mathrm{RC}_{a}$ values (Figure 9). These values were derived from different studies where reduced tillage or no tillage techniques were applied (Chisci, 1989; Puustinen et al., 2005, 2007). Also for $\Delta \mathrm{SL}_{a}, 8$ negative values were noted for $\mathrm{SL}_{a C O N V}$ rates larger than $2 \mathrm{Mg} \cdot \mathrm{ha}^{-1} \cdot \mathrm{yr}^{-1}$. Again, these points correspond to paired plot studies where tillage techniques (no-tillage, reduced tillage and contour tillage) were tested at different locations and under different land uses. This indicates that the lack of effectiveness is inherent to the tillage techniques, rather than depending on environmental conditions or measuring uncertainties. 
To further explore relations between annual RR and SLR and plot slope length, slope gradient and annual precipitation depth for individual SWCTs, weighted regression equations of the type:

$$
Y=a X^{b}
$$

were calculated, whereby each observation in the regression was weighted by the square root of \#PY corresponding to the plot measurement. The limited number of regressions for which the b-value is significantly different from $0(\alpha=0.05)$ indicates that the effect of plot slope length, plot slope gradient and $\mathrm{Pa}$ on SWCT effectiveness is limited (Table 5). For instance, no slope gradient and slope length effects on contour tillage effectiveness were found, even though both factors are used in the calculation of the P-factor for contour tillage (Renard et al., 1997). Nevertheless, all exponents (b) of the significant regressions are negative (Table 5), indicating that these SWCTs become more effective in more erosion-prone conditions (i.e. longer and steeper plot slopes and higher Pa). This is in line with results reported by Smets et al. (2008b,a) who observed that various soil surface cover types (i.e. organic and inorganic mulches, vegetation) become more effective in reducing SL on longer plots.

Table 5: Summary of the significant regressions $\left(\mathrm{Y}=\mathrm{aX}{ }^{b}\right.$, Eq. 5) between annual runoff ratio (RR), annual soil loss ratio (SLR) and plot slope length, plot slope gradient and annual precipitation for each of the soil and water conservation techniques (SWCTs). Only regressions significant at $\alpha=0.05$ are given. \#PL: number of plots, a: regression coefficient, b: regression exponent, p: p-value; probability that the b-value is not significantly different from zero. $\mathrm{r}^{2}$ : coefficient of determination.

\begin{tabular}{|c|c|c|c|c|c|c|}
\hline variable & SWCT & $\# \mathbf{P L}$ & $\mathbf{a}$ & b & $\mathbf{p}$ & $\mathbf{r}^{2}$ \\
\hline \multicolumn{7}{|c|}{ RR } \\
\hline \multicolumn{7}{|c|}{ slope gradient } \\
\hline & mulching & 13 & 3.28 & -0.88 & 0.02 & 0.42 \\
\hline & strip cropping & 12 & 174.49 & -1.83 & 0.01 & 0.55 \\
\hline \multicolumn{7}{|c|}{ annual precipitation } \\
\hline & contour tillage & 29 & 43.57 & -0.66 & $<0.01$ & 0.27 \\
\hline & geotextile & 14 & $2.04 \times 10^{5}$ & -1.94 & 0.01 & 0.43 \\
\hline \multicolumn{7}{|c|}{ SLR } \\
\hline \multicolumn{7}{|c|}{ plot length } \\
\hline & cover crops & 18 & 3.80 & -1.06 & 0.04 & 0.25 \\
\hline & terraces & 14 & 527.62 & -2.67 & $<0.01$ & 0.59 \\
\hline \multicolumn{7}{|c|}{ annual precipitation } \\
\hline & mulching & 14 & 861.36 & -1.62 & 0.04 & 0.31 \\
\hline & no-tillage & 24 & 424.32 & -1.02 & 0.04 & 0.18 \\
\hline & terraces & 14 & $3.6 \times 10^{8}$ & -3.42 & $<0.01$ & 0.63 \\
\hline
\end{tabular}

The overall absence of clear relations between RR or SLR and plot slope length, plot slope gradient or Pa may be partly attributable to differences in other environmental and experimental conditions of the plot studies. These differences are hard to account for, because these conditions were rarely specified in the original data sources. For instance, rainfall distribution and intensity may have a large influence on RR and SLR, since $\mathrm{R}_{a}$ and $\mathrm{SL}_{a}$ often depend on a few low-frequency, high-magnitude events (e.g. de Figueiredo and Poesen, 1998). Unfortunately, insufficient rainfall distribution and intensity data were available to investigate potential relations with SWCT effectiveness. Likewise, soil characteristics may significantly control RR and SLR. However, no data were available to quantify this effect. Furthermore, the calculated regressions (Table 5) are strongly controlled by a few observations with a very high plot length or gradient. This further increases the uncertainty on the calculated relationships. As a result, our results remain inconclusive about the overall effects of environmental factors on the effectiveness of SWCTs. 


\section{Temporal variability and trends in the effectiveness of SWCTs: the case of tillage techniques}

Mean measuring period for plots in the PP database was 4.9 yrs. (st. dev.: 11.2 yrs, median: 2 yrs., mode: 1 yr.). Hence, most studies focus on the quantification of the effectiveness directly after application of the SWCT, while temporal variability and evolution of SWCT effectiveness over time is largely ignored.

To explore the effectiveness of SWCTs during consecutive years, 65 time-series of annual paired plot $\mathrm{R}_{a}$ and/or $\mathrm{SL}_{a}$ observations were selected from the PP database. At these plots, the effectiveness of no-tillage, reduced tillage or contour tillage under cropland was tested for a period of at least 3 consecutive years. To increase the number of available data, also studies from alsewhere where the effectiveness of no-tillage, contour tillage or reduced tillage under cropland was evaluated were included. These other studies include time-series from 18 paired plots from the United States (Bosch et al., 2005; Cullum et al., 2007, 2010; McCool et al., 2008; McDowell and McGregor, 1984; Schreiber and Cullum, 1998; Shipitalo and Edwards, 1998) and 12 plot data time-series from Australia (Freebairn and Wockner, 1986).

Figure 10 shows that there is considerable variability in RR and SLR for individual paired plots between the different years, independent of the time after SWCT application. The median trend of the RR and SLR over the consecutive years since the first application of the tillage techniques (Figure 10) shows that for no-tillage, RR are generally larger than SLR throughout the measuring period and tend to increase over the years following first application. Hence, the effectiveness of these techniques to reduce runoff decreases over time. No such trend is observed for SLR. This is most likely attributable to increasing surface sealing when the soil is not tilled for several years. While this is beneficial for $\mathrm{SL}_{a}$ reduction, it also reduces infiltration capacity of the soil and thus enhances $\mathrm{R}_{a}$ (Bradford et al., 1987). Similar, but less clear trends can be noted for reduced tillage and contour tillage (Figure 10). The number of sufficiently long time-series is limited however. As a result, these trends should be interpreted with caution as they may not be globally valid. 


\section{no-tillage}
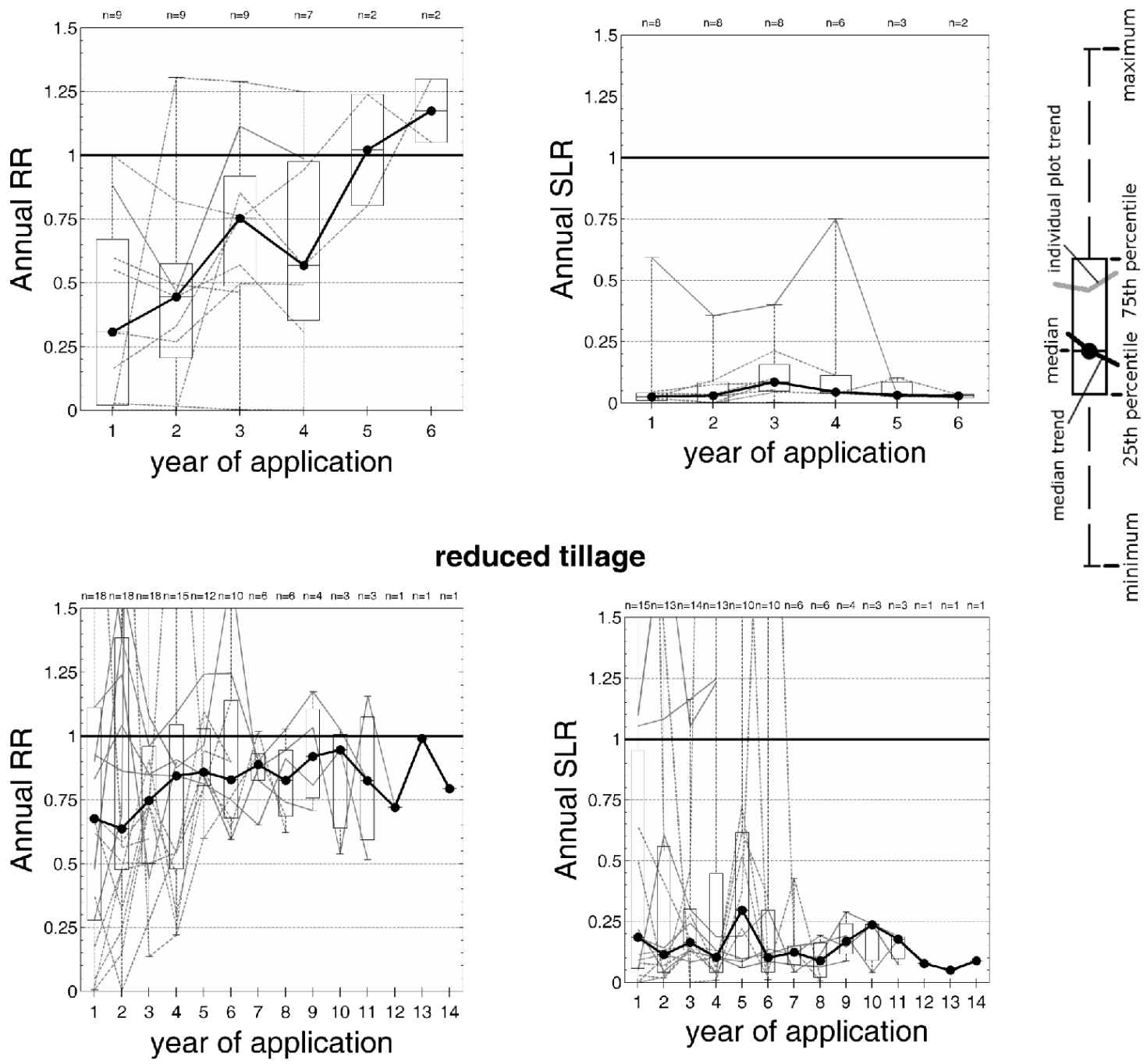

contour tillage
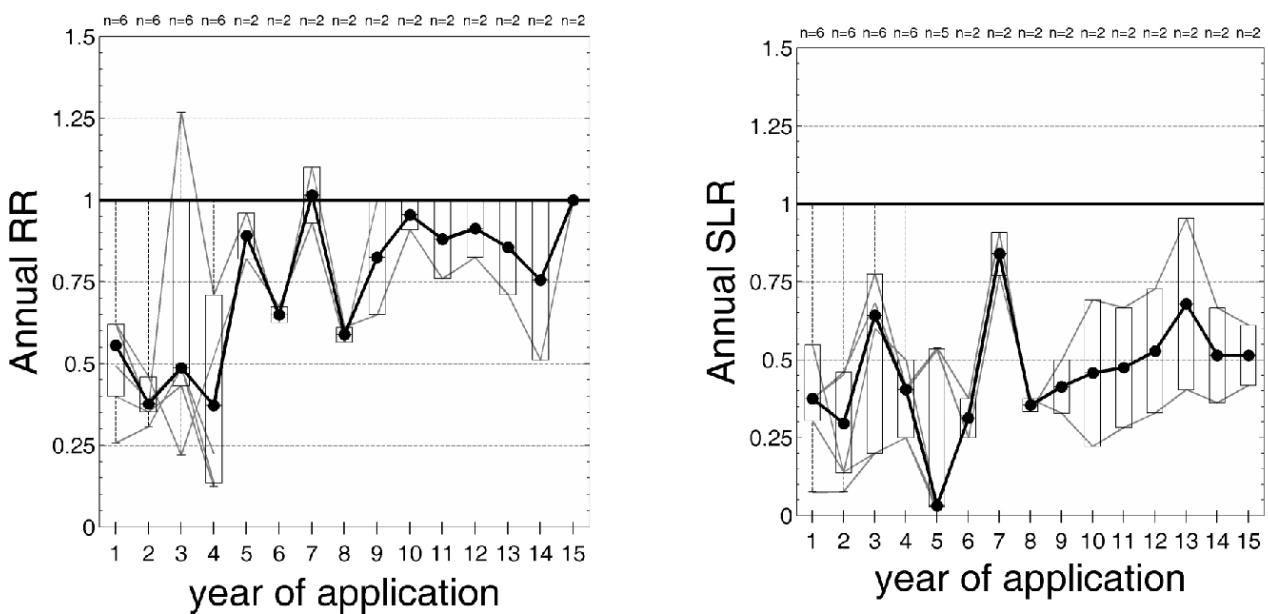

Figure 10: Frequency distribution (box plots) and median trend (black solid line) of annual runoff ratio (RR, Eq. 1) and annual soil loss ratio (SLR, Eq. 2) for consecutive years following the application of a soil and water conservation technique. All studies were conducted on plots under cropland. Thin grey solid lines indicate trends for individual plots in Europe and the Mediterranean, thin grey dashed lines indicate trends for individual plots in the U.S.A. or Australia. $\mathrm{n}=$ number of plots. 


\section{Conclusions}

This study is the first to present a meta-analysis of field-measured plot data on the effectiveness of soil and water conservation techniques in reducing annual runoff $\left(\mathrm{R}_{a}\right)$ and annual soil loss $\left(\mathrm{SL}_{a}\right)$ for the Europe and the Mediterranean. Its results allow one to estimate the effectiveness of different SWCTs in reducing both $\mathrm{R}_{a}$ and/or $\mathrm{SL}_{a}$. Crop and vegetation management (buffer strips, mulching, cover crops) and mechanical methods (geotextiles, terraces, contour bunds) are more effective in reducing $\mathrm{R}_{a}$ and $\mathrm{SL}_{a}$ than soil management techniques (no-tillage, reduced tillage, contour tillage). Nevertheless, large research efforts have been invested in these soil management techniques, while potentially more effective techniques remain relatively underresearched. A key finding of this study is that SWCTs are generally much more effective in reducing soil loss than in reducing runoff. This is important to consider, since reducing runoff and promoting infiltration may be a much bigger concern than reducing soil loss. Both for soil loss and runoff, the measured effectiveness for a given SWCT varies widely between different studies, indicating an effect of environmental factors. However, due to a lack of data the factors controlling this variability could not be clearly identified. Some of the studied soil and water conservation techniques become more effective in reducing $\mathrm{R}_{a}$ and $\mathrm{SL}_{a}$ rates in more erosion-prone conditions, i.e. when larger $\mathrm{R}_{a}$ and $\mathrm{SL}_{a}$ are measured on the plot with conventional practice, on longer and steeper slopes or in areas with a higher annual precipitation depth. However, observed relations between these factors and RR and SLR are weak and future studies should aim to better identify factors controlling the effectiveness of SWCTs in reducing $\mathrm{R}_{a}$ and $\mathrm{SL}_{a}$, as this is a key requirement for their successful implementation.

Furthermore, the effectiveness of a SWCT may show important temporal variations. For no-tillage and, to a lesser extent, reduced tillage and contour tillage, clear indications were found that these techniques become less effective in reducing runoff after consecutive years of application. These longer-term trends, as well as the inter-annual variability of SWCT effectiveness are important factors to be further explored, as they will contribute to a better selection of these techniques to conserve both our soils and water resources. This will require studies evaluating the effectiveness of SWCTs over longer time periods (i.e. $>3$ years). Unfortunately, such studies are currently rare.

\section{Acknowledgements}

The research reported in this paper was conducted in the framework of the EC-DG RTD - 6th Framework Research Programme (sub-priority 1.1.6.3) - Research on Desertification - project DESIRE (037046): Desertification Mitigation and Remediation of land - a global approach for local solutions (http://www. desire-project.eu). M. Vanmaercke received grant-aided support from the Research Foundation Flanders (FWO), Belgium. The authors thank the many researchers who provided publications and additional information on their plot measurements. 


\section{References}

Abu Hammad, A. H., Borresen, T., Haugen, L. E., 2006. Effects of rain characteristics and terracing on runoff and erosion under the Mediterranean. Soil \& Tillage Research 87 (1), $39-47$.

Abu Hammad, A. H., Haugen, L. E., Borresen, T., 2004. Effects of stonewalled terracing techniques on soil-water conservation and wheat production under Mediterranean conditions. Environmental Management 34 (5), 701-710.

Abu-Zreig, M., 2006. Control of rainfall-induced soil erosion with various types of polyacrylamide. Journal of Soils and Sediments 6 (3), 137-144.

Abu-Zreig, M., Tamimi, A., Alazba, A., 2011. Soil Erosion Control and Moisture Conservation of Arid Lands with Stone Cover. Arid Land Research and Management 25 (3), 294-307.

Agassi, M., Benhur, M., 1991. Effect Of Slope Length, Aspect And Phosphogypsum On Runoff And Erosion From Steep Slopes. Australian Journal of Soil Research 29 (2), 197-207.

Agassi, M., Shainberg, I., Morin, J., 1990. Slope, Aspect and Phosphogypsum Effects on Runoff and Erosion. Soil Science Society of America Journal 54 (4), 1102-1106.

Al-Seekh, S., Mohammad, A., 2009. The Effect of Water Harvesting Techniques on Runoff, Sedimentation, and Soil Properties. Environmental Management 44 (1), 37-45.

Albaladejo, J., Castillo, V., Diaz, E., 2000. Soil loss and runoff on semiarid land as amended with urban solid refuse. Land Degradation \& Development 11 (4), 363-373.

Ali, A., 2007. Evaluating the effect of micro-catchment water harvesting on water and soil losses in the dryland catchment. Phd. thesis, Çukurova University, Department of Agricultural Structures and Irrigation. Institute of Natural and Applied Sciences., Adana, Turkey, 238 pp.

Arabi, M., Roose, E., 1993. Gestion conservatoire de l'eau et de la fertilité des sols en montagne semi-aride Algérienne. Bull. Réseau Erosion 18, 230-240.

AREDVI, 2003. Guide de Protection du vignoble 2003. Association Régionale d' Expérimentation et de Développement Viti-vinicole, Aix-en-Provence, 82 pp.

Aspizua, R., 2003. Erosion Assessment and Conservation Measures in Sloping and Mountainous Olive Production Systems in Andalucía. 77 pp.

Auerswald, K., Fiener, P., Dikau, R., 2009. Rates of sheet and rill erosion in Germany - A meta-analysis. Geomorphology 111 (3-4), 182-193.

Ballif, J., 1989. Erosion dans le vignoble champenois : influence des techniques culturales (France). Cahiers ORSTOM, Séries Pedologie XXV (1-2), 151-156.

Basic, F., Kisic, I., Butorac, A., Nestroy, O., Mesic, M., 2001. Runoff and soil loss under different tillage methods on Stagnic Luvisols in central Croatia. Soil \& Tillage Research 62 (3-4), 145151.

Basic, F., Kisic, I., Mesic, M., Nestroy, O., Butorac, A., 2004. Tillage and crop management effects on soil erosion in central Croatia. Soil \& Tillage Research 78 (2), 197-206.

Basso, F., Barbieri, G., Linsalata, D., 1983. Relation between hydrological parameters and erosion of a clay soil at 2 year rotation horsebean for seed durum wheat under different tillage systems. (In Italian: Relazione tra parametri idrologici ed erosione di un terreno argilloso 
a rotazione biennale: Favino da seme-frumento duro sottoposto a differenti modalità di lavorazione.). In: Problemi Agronomici per la Difesa dai Fenomeni Erosivi, Quaderni della Ricerca del CNR n.129. 129. CNR, Roma, pp. 186-207.

Bautista, S., Bellot, J., Vallejo, V. R., 1996. Mulching treatment for postfire soil conservation in a semiarid ecosystem. Arid Soil Research and Rehabilitation 10 (3), 235 - 242.

Bhattacharyya, R., Davies, K., Fullen, M., Booth, C., 2008. Effects of Palm-mat Geotextiles on the Conservation of Loamy Sand Soils in East Shropshire, UK. Advances in Geoecology 39, $527-538$.

Bhattacharyya, R., Fullen, M. A., Davies, K., Booth, C. A., 2009. Utilizing palm-leaf geotextile mats to conserve loamy sand soil in the United Kingdom. Agriculture Ecosystems \& Environment 130 (1-2), 50-58.

Bienes, R., Marqués, M., Jiménez, L., Pérez, R., 2006. Study and quantification of the loss of fertility by water erosion. In: Proceedings of the 4th Conference of International Soil Conservation Organization. Water Management and Soil Conservation in Semi-Arid Environments. Marrakech, Morocco, 14-19 May. ISCO, Marrakech, Morocco, 143-144 pp.

Bini, C., Gemignani, S., Zilocchi, L., 2006. Effect of different land use on soil erosion in the pre-alpine fringe (North-East Italy): Ion budget and sediment yield. Science of The Total Environment 369 (1-3), 433-440.

Biolchev, A., 1975. Water regulating and anti-erosion effect of forest and grass strips. In: Scientific Works of VLTI 20. 20, 63-69 pp.

Boardman, J., Poesen, J., 2006. Soil Erosion in Europe. Wiley, Chichester, 878 pp.

Bosch, D., Potter, T., Truman, C., Bednarz, C., Strickland, T., 2005. Surface runoff and lateral subsurface flow as a response to conservation tillage and soil-water conditions. American Society of Agricultural and Biological Engineers 46 (6), 2137-2144.

Bradford, J. M., Ferris, J. E., Remley, P. A., 1987. Interrill Soil Erosion Processes: I. Effect of Surface Sealing on Infiltration, Runoff, and Soil Splash Detachment. Soil Science Society of America Journal 51 (6), 1566-1571.

Brown, L., 1996. Effect and interaction of rotation, cultivation and agrochemical input levels on soil erosion and nutrient emissions. Aspects of Applied Biology 47, 409-412.

Bruggeman, A., Masri, Z., Turtelboom, F., 2005. Strategies to sustain productivity of olive groves on steep slopes in the northwest of the Syrian Arab republic. In: Benites, J., Pisante, M., Stagnari, F. (Eds.), Integrated Soil and Water Management for Orchard Development; Role and Importance. FAO Land and Water Bulletin 10. 10. FAO, Rome, pp. 75-87.

Caredda, S., Porqueddu, C., Sulas, L., Solinas, V., Bazonni, A., 1997. Analisi ambientale di sistemi cerealicolo-zootecnici sardi: aspetti erosivi. Nota I. Agricoltura Ricera 170, 43-50.

Castillo, V. M., MartinezMena, M., Albaladejo, J., 1997. Runoff and soil loss response to vegetation removal in a semiarid environment. Soil Science Society of America Journal 61 (4), $1116-1121$.

Cerdà, A., Flanagan, D. C., le Bissonnais, Y., Boardman, J., 2009. Soil erosion and agriculture. Soil \& Tillage Research 106 (1), 107-108. 
Cerdan, O., Govers, G., Le Bissonnais, Y., Van Oost, K., Poesen, J., Saby, N., Gobin, A., Vacca, A., Quinton, J., Auerswald, K., Klik, A., Kwaad, F. J. P. M., Raclot, D., Ionita, I., Rejman, J., Rousseva, S., Muxart, T., Roxo, M. J., Dostal, T., 2010. Rates and spatial variations of soil erosion in Europe: A study based on erosion plot data. Geomorphology 122 (1-2), 167-177.

Cerdan, O., Poesen, J., Govers, G., Saby, N., Le Bissonnais, Y., Gobin, A., Vacca, A., Quinton, J., Auerswald, K., Klik, A., Kwaad, F. F. P. M., Roxo, M. J., 2006. Sheet and Rill Erosion. In: Boardman, J., Poesen, J. (Eds.), Soil Erosion in Europe. Wiley, Chichester, pp. 501-513.

Chisci, G., 1989. Measures for runoff and erosion control on clayey soils: a review of trails carried out in the Apennines hilly area. In: Schwertmann, U., Rickson, R., Auerswald, K. (Eds.), Soil Erosion Protection Measures in Europe. Soil Technology Series No.1. Catena Verlag, Cremlingen, 53-71 pp.

Chisci, G., Zanchi, C., 1981. The influence of different tillage systems and different crops on soil losses on hilly silty-clayey soil. In: Morgan, R. P. C. (Ed.), Soil Conservation: Problems and Prospects. Wiley, Chichester, pp. 211-217.

Chomanicová, A., 1988. Erózne procesy vo flysovej oblasti. VÚPÚ, Bratislava, Slovakia.

Cogo, N. P., Moldenhauer, W. C., Foster, G. R., 1984. Soil Loss Reductions from Conservation Tillage Practices. Soil Science Society of America Journal 48 (2), 368-373.

Conley, D. J., 2000. Biogeochemical nutrient cycles and nutrient management strategies. Hydrobiologia $410(0), 87-96$.

Cullum, R., Locke, M., Knight, S., 2010. Effects of conservation reserve program on runoff and lake water quality in an oxbow lake watershed. Journal of International Environmental Application \& Science 5 (3), 318-328.

Cullum, R. F., Wilson, G. V., McGregor, K. C., Johnson, J. R., 2007. Runoff and soil loss from ultra-narrow row cotton plots with and without stiff-grass hedges. Soil \& Tillage Research $93(1), 56-63$.

de Figueiredo, T., Poesen, J., 1998. Effects of surface rock fragment characteristics on interrill runoff and erosion of a silty loam soil. Soil \& Tillage Research 46 (1-2), 81-95.

de Vente, J., 2009. Soil Erosion and Sediment Yield in Mediterranean Geoecosystems - Scale issues, modelling and understanding -. Phd. thesis, KU Leuven, Department of Earth and Environmental Sciences, Leuven, 264 pp.

de Vente, J., Poesen, J., Arabkhedri, M., Verstraeten, G., 2007. The sediment delivery problem revisited. Progress in Physical Geography 31 (2), 155-178.

DESIRE, 2007. Desertification mitigation and remediation of land - a global approach for local solutions (DESIRE). Available at: http://www. desire-project.eu/ (accessed 1 March 2012).

Djorović, M., 1990. Experimental-Study Of Erosion And Crop Production On Bench Terraces On Sloping Land. In: Boardman, J., Foster, I., Dearing, J. (Eds.), Soil Erosion on Agricultural Land. Wiley, Chichester, pp. 531-536.

Emde, K., 1992. Experimentelle Untersuchungen zu Oberflächenabfluß und Bodenaustrag in Verbindung mit Starkregen bei verschiedenen Bewirtschaftungssystemen in Weinbergsarealen des oberen Rheingaus. Geisenheimer Berichte 12.

European Commission, 13 February 2012 2012. The implementation of the Soil Thematic Strategy and ongoing activities. European Commission, Brussels. 
Feiza, V., Feiziene, D., Jankauskas, B., Jankauskiene, G., Slepetiene, A., 2007. Soil use and management impact on surface runoff and SOM/SOC content on hilly landscape of lithuania. In: Off-site Impacts of Soil Erosion and Sediment Transport. Proceedings of the COST 634 Erosion International Conference. Prague, Czech Republic, 1-3 October, pp. 55-72.

Fleskens, L., Stroosnijder, L., 2007. Is soil erosion in olive groves as bad as often claimed? Geoderma 141 (3-4), 260-271.

Francia Martínez, J. R., Durán Zuazo, V. H., Martínez Raya, A., 2006. Environmental impact from mountainous olive orchards under different soil-management systems (SE Spain). Science of The Total Environment 358 (1-3), 46-60.

Freebairn, D., Wockner, G., 1986. A study of soil erosion on vertisols of the eastern Darling Downs, Queensland. I. Effects of surface conditions on soil movement within Contour Bay catchments. Australian Journal of Soil Research 24, 135-158.

Fulajtár, E., Janský, L., 2001. Soil Erosion and Soil Conservation (In Slovak: Vodná erózia pôdy a protierózna ochrana.). VÚPOP a PRIFUK, Bratislava.

Gilley, J. E., Risse, L. M., 2000. Runoff and Soil Loss as Affected by the Application of Manure. Transactions of the ASAE 43 (6), 1583-1588.

Gómez, J. A., Guzmán, M. G., Giráldez, J. V., Fereres, E., 2009. The influence of cover crops and tillage on water and sediment yield, and on nutrient, and organic matter losses in an olive orchard on a sandy loam soil. Soil \& Tillage Research 106 (1), 137-144.

Gómez, J. A., Romero, P., Giraldez, J. V., Fereres, E., 2004. Experimental assessment of runoff and soil erosion in an olive grove on a Vertic soil in southern Spain as affected by soil management. Soil Use and Management 20 (4), 426-431.

Gonzalez-Hidalgo, J. C., Batalla, R. J., Cerdà, A., de Luis, M., 2010. Contribution of the largest events to suspended sediment transport across the USA. Land Degradation \& Development $21(2), 83-91$.

González-Hidalgo, J. C., Peña-Monné, J. L., de Luis, M., 2007. A review of daily soil erosion in Western Mediterranean areas. Catena 71 (2), 193-199.

Govers, G., Poesen, J., 1988. Assessment of the interrill and rill contributions to total soil loss from an upland field plot. Geomorphology 1 (4), 343-354.

Grazhdani, S., Jacquin, F., Sulce, S., 1996. Effect of subsurface drainage on nutrient pollution of surface waters in south eastern Albania. Science of The Total Environment 191 (1-2), 15-21.

Grazhdani, S., Sulejman, S., Dhima, S., 1999. Conserving farming effect on soil and nutrient erosion in agricultural land of mountainous terrain. Journal of Natural and Technical Sciences 6, 23-32.

Grønsten, H. A., Lundekvam, H., 2006. Prediction of surface runoff and soil loss in southeastern Norway using the WEPP Hillslope model. Soil \& Tillage Research 85 (1-2), 186-199.

Hao, Y., Lal, R., Owens, L. B., Izaurralde, R. C., Post, W. M., Hothem, D. L., 2002. Effect of cropland management and slope position on soil organic carbon pool at the North Appalachian Experimental Watersheds. Soil \& Tillage Research 68 (2), 133-142.

Hessel, R., Tenge, A., 2008. A pragmatic approach to modelling soil and water conservation measures with a catchment scale erosion model. Catena 74 (2), 119-126. 
Heusch, B., 1970. L'érosion hydraulique au Maroc: son calcul et son controle. Al Awamia 36, 39-63.

Hudek, C., Rey, F., 2009. Studying The Effects Of Mahonia Aquifolium Populations On SmallScale Mountain Agro-Ecosystems In Hungary With The View To Minimise Land Degradation. Land Degradation \& Development 20 (3), 252-260.

Ingelmo, F., Ibáñez, A., Pomares, F., Garcia, J., Mares, M., 1998. Measures for soil protection in citrus orchards and in abandoned fields in the community of Valencia (Spain). In: Rodríguez Rodríguez, A., Jiménez Mendoza, C., Tejedor Salguero, M. (Eds.), The Soil as a Strategic Resource: Degradation Processes and Conservation Measures. Geoforma Ediciones, Logroño, pp. 431-439.

Jankauskas, B., Jankauskiene, G., 2003. Long-term soil erosion studies on the Žemaiciai upland: 2. Intensity of water erosion. Žemdirbyste. Mokslo Darbai 82, 20-34.

Jankauskas, B., Jankauskiene, G., Fullen, M., 2007. Soil erosion and changes in the physical properties of Lithuanian Eutric Albeluvisols under different land use systems. Acta Agricultura Scandinavica, Section B - Soil and Plant Science 58 (1), 66-76.

Jankauskas, B., Jankauskiene, G., Fullen, M., Booth, C., 2008. Utilizing palm-leaf geotextiles to control soil erosion on roadside slopes in Lithuania. Žemes Ukio Mokslai 15 (3), 22-28.

Jung, L., Brechtel, R., 1980. Messung von Oberflächenabfluß und Bodenabtrag auf verschiedenen Böden der BRD. Parey, Hamburg.

Kaabia, M., 1995. Effets de quelques systèmes de culture sur l'érosion hydrique, le ruissellement et la fertilité du sol dans le semi-aride Tunisien. Bull. Réseau Erosion 15, 382-392.

Karlen, D. L., 2008. A new paradigm for natural resources research: The Conservation Effects Assessment Project. Journal of Soil and Water Conservation 63 (6), 220A.

Kertesz, A., Toth, A., Szalai, Z., 2007. The role of geotextiles in soil erosion and runoff control. In: Off-site Impacts of Soil Erosion and Sediment Transport. Proceedings of the COST 634 Erosion International Conference. Prague, Czech Republic, 1-3 October, pp. 45-53.

Klik, A., 2003. The impact of different tillage practices on surface runoff, soil erosion and nutrient and pesticide losses. (In German: Einfluss unterschiedlicher Bodenbearbeitung auf Oberflächenabfluss, Bodenabtrag sowie auf Nährstoff- und Pestizidausträge.). Österreichische Wasser- und Abfallwirtschaft 55 (5-6), 89-96.

Klik, A., 2010. Agronomische Bodenschutzmaßnahmen und ihre Auswirkungen. In: Umweltökologisches Symposium. Raumberg-Gumpenstein, Austria, 2-3 March. 2. Lehr- und Forschungszentrum für Landwirtschaft, Raumberg-Gumpenstein, Austria, pp. 17-22.

Kosmas, C., Danalatos, N., Cammeraat, L. H., Chabart, M., Diamantopoulos, J., Farand, R., Gutierrez, L., Jacob, A., Marques, H., Martinez-Fernandez, J., Mizara, A., Moustakas, N., Nicolau, J. M., Oliveros, C., Pinna, G., Puddu, R., Puigdefabregas, J., Roxo, M., Simao, A., Stamou, G., Tomasi, N., Usai, D., Vacca, A., 1997. The effect of land use on runoff and soil erosion rates under Mediterranean conditions. Catena 29 (1), 45-59.

Koulouri, M., Giourga, C., 2007. Land abandonment and slope gradient as key factors of soil erosion in Mediterranean terraced lands. Catena 69 (3), 274-281.

Kroumov, V., Malinov, I., 1989. Erosion-protection efficiency of naturally regenerating plants on strongly degraded pastures. Soil Science and Agrochemistry 24 (5), 75-79. 
Köse, C., Taysun, A., 2002. Su havzalarinda toprak ve su kaynaklarinin korunmasi, Gelistirilmesi ve yönetimi sempozyumu. In: Önder, S. (Ed.), Türkiye tarim alanlarinda erozyon kontrolü bakimindan seritvari tarim sisteminin etkisi ve önemi. Antakya, Turkey, 18-20 September. Mustafa Kemal University - Faculty of Agriculture, Antakya, Turkey, pp. 364-370.

Köse, C., Yakar, M., Taysun, A., 1996. Effect of strip-cropping system on water erosion in Gediz Basin. In: Toprak ve su Kaynaklari Araştirma Yilliği (Soil and Water Resources Research Yearbook). 102. Köy Hizmetleri Genel Müdürlüğü - Apk Dairesi Başkanligi, pp. 52-68.

Kwaad, F. J. P. M., van der Zijp, M., van Dijk, P. M., 1998. Soil conservation and maize cropping systems on sloping loess soils in the Netherlands. Soil \& Tillage Research 46 (1-2), 13-21.

Laflen, J., Moldenhauer, W., 2003. Pioneering Soil Erosion Prediction. The USLE Story. World Association of Soil \& Water Conservation - WASWC. Special Publication No. 1. 54 pp.

Laloy, E., Bielders, C. L., 2008. Plot scale continuous modelling of runoff in a maize cropping system with dynamic soil surface properties. Journal of Hydrology 349 (3-4), 455-469.

Laloy, E., Bielders, C. L., 2010. Effect of Intercropping Period Management on Runoff and Erosion in a Maize Cropping System. Journal of Environmental Quality 39 (3), 1001-1008.

Laouina, A., Chaker, M., Naafa, R., 2003. Suivi et mesure de l'érosion hydrique des terres au Marco, 15 ans de recherche et d'expérimentation. Rev. Géogr. Maroc 21, 79-98.

Le Bissonnais, Y., Lecomte, V., Cerdan, O., 2004. Grass strip effects on runoff and soil loss. Agronomie 24 (3), 129-136.

Leys, A., Govers, G., Gillijns, K., Berckmoes, E., Takken, I., 2010. Scale effects on runoff and erosion losses from arable land under conservation and conventional tillage: The role of residue cover. Journal of Hydrology 390 (3-4), 143-154.

Llovet, J., Ruiz-Valera, M., Josa, R., Ramon Vallejo, V., 2009. Soil responses to fire in Mediterranean forest landscapes in relation to the previous stage of land abandonment. International Journal of Wildland Fire 2009 (18), 222-232.

Lopez-Bermudez, F., Romero-Díaz, A., Martinez-Fernandez, J., 1991. Soil erosion in a semi-arid Mediterranean environment. El Ardal experimental field (Murcia, Spain). In: Sala, M., Rubio, J. L., García-Ruiz, J. (Eds.), Soil Erosion Studies in Spain. Geoforma Ediciones, Logroño, pp. $137-152$.

Louwagie, G., Gay, S., Burrell, A., 2009. Final Report on the Project 'Sustainable Agriculture and Soil Conservation (SoCo)'. JRC Scientific and Technical Reports, JRC 51775 - EUR 23820 EN. Luxembourg, Luxembourg, 170 pp.

Lundekvam, H. E., 2007. Plot studies and modelling of hydrology and erosion in southeast Norway. Catena 71 (2), 200-209.

Madejón, E., Murillo, J., Moreno, F., López, M., Arrue, J., Alvaro-Fuentes, J., Cantero, C., 2009. Effect of long-term conservation tillage on soil biochemical properties in Mediterranean Spanish areas. Soil \& Tillage Research 105 (1), 55-62.

Maetens, W., Vanmaercke, M., Poesen, J., Jankauskas, B., Jankauskiene, G., Ionita, I., 2012. Effects of land use on annual runoff and soil loss in Europe and the Mediterranean: A metaanalysis of plot data. Progress in Physical Geography 36 (5), 597 - 651.

Malinov, I., 1999. Study on the soil water erosion for slope with grass and forest strip belts. Phd. thesis, N Poushkarov Institute for Soil Science, Sofia, Bulgaria. 
Martinez-Mena, M., Rogel, J. A., Albaladejo, J., Castillo, V. M., 1999. Influence of vegetal cover on sediment particle size distribution in natural rainfall conditions in a semiarid environment. Catena 38 (3), 175-190.

Martinez Raya, A., Durán Zuazo, V. H., Francia Martinez, J. R., 2006. Soil erosion and runoff response to plant-cover strips on semiarid slopes (SE Spain). Land Degradation \& Development $17(1), 1-11$.

Martínez-Casasnovas, J. A., Ramos, M. C., 2006. The cost of soil erosion in vineyard fields in the Penedès-Anoia Region (NE Spain). Catena 68 (2-3), 194-199.

Masri, Z., El-Naeb, H., Zöbisch, M., Bruggeman, A., Turkelboom, F., 2005. Land management strategies to sustain producitvity of olive groves on steep slopes in northwest Syria. In: Benites, J., Pisante, M., Stagnari, F. (Eds.), Integrated Soil and Water Management for Orchard Development; Role and Importance. FAO Land and Water Bulletin 10. 10. FAO, Rome, pp. $75-91$.

Mazour, M., 1992. Les facteurs de risque de l' érosion en nappe dans le bassin versant D'Isser, Tlemcen Algerie. Bull. Réseau Erosion 12, 300-313.

Mazour, M., Boughalem, M., Mededjel, N., 2008. La gestion de la matière organique et ses effets sur la conservation de la fertilité du sol dans le nord-ouest de l'algérie. In: Roose, E., Albergel, J., De Noni, G., Laouina, A., Sabir, M. (Eds.), Efficacité de la Gestion de l'Eau et de la Fertilité des Sols en Milieux Semi-arides. Actualité Scientifique. AUF, EAC et IRD éditeurs, Paris, pp. 175-181.

McCool, D. K., Pannkuk, C. D., Kennedy, A. C., Fletcher, P. S., 2008. Effects of burn/low-till on erosion and soil quality. Soil \& Tillage Research 101 (1-2), 2-9.

McDowell, L. L., McGregor, K. C., 1984. Plant nutrient losses in runoff from conservation tillage corn. Soil \& Tillage Research 4 (1), 79-91.

Mücher, C. A., Klijn, J. A., Wascher, D. M., Schaminée, J. H. J., 2010. A new European Landscape Classification (LANMAP): A transparent, flexible and user-oriented methodology to distinguish landscapes. Ecological Indicators 10 (1), 87-103.

Messer, T., 1980. Soil erosion measurements on experimental plots in Alsace vineyards (France). In: De Boodt, M., Gabriëls, D. (Eds.), Assessment of Erosion. Wiley, Chichester, pp. 455-462.

Metzger, M. J., Bunce, R. G. H., Jongman, R. H. G., Mücher, C. A., Watkins, J. W., 2005. A climatic stratification of the environment of Europe. Global Ecology and Biogeography 14 (6), $549-563$.

Mitchell, D., Barton, A., Fullen, M., Hocking, T., Zhi, W. B., Yi, Z., 2003. Field studies of the effects of jute geotextiles on runoff and erosion in Shropshire, UK. Soil Use and Management 19 (2), 182-184.

Montgomery, D., 2007a. Dirt: The Erosion of Civilizations. University of California Press, Berkeley and Los Angeles, California.

Montgomery, D. R., 2007b. Soil erosion and agricultural sustainability. Proceedings of the National Academy of Sciences of the United States of America 104 (33), 13268-13272.

Morgan, R., 2005. Soil Erosion and Conservation, 3rd Edition. Blackwell, Oxford, 320 pp.

Morsli, B., Mazour, M., Mededjel, N., Hamoudi, A., Roose, E., 2004. Influence de l'utilisation des terres sur les risques de ruissellement et d'érosion sur les versants semi-arides du nord-ouest de l'Algérie. Science et Changements Planétaires / Sécheresse 15, 96-104. 
Nearing, M., Govers, G., Norton, L., 1999. Variability in soil erosion data from replicated plots. Soil Science Society of America Journal 63 (6), 1829-1835.

Nearing, M. A., Jetten, V., Baffaut, C., Cerdan, O., Couturier, A., Hernandez, M., Le Bissonnais, Y., Nichols, M. H., Nunes, J. P., Renschler, C. S., Souchère, V., Van Oost, K., 2005. Modeling response of soil erosion and runoff to changes in precipitation and cover. Catena 61 (2-3), $131-154$.

Nistor, D., Ionita, I., 2002. Development of soil erosion control in Romania. In: Rubio, J. L., Morgan, R., Asins, S., Andreu, V. (Eds.), Proceedings of the third International Congress Man and Soil at the Third Millennium. Logroño, 28 March - 1 April. Geoforma Ediciones, Logroño, pp. 299-309.

Nyssen, J., Clymans, W., Descheemaeker, K., Poesen, J., Vandecasteele, I., Vanmaercke, M., Zenebe, A., Van Camp, M., Haile, M., Haregeweyn, N., Moeyersons, J., Martens, K., Gebreyohannes, T., Deckers, J., Walraevens, K., 2010. Impact of soil and water conservation measures on catchment hydrological response-a case in north Ethiopia. Hydrological Processes 24 (13), $1880-1895$.

Oguz, I., Cebel, H., Özden, S., Ayday, E., Demiryürek, M., 2006. Türkiye Üniversal Denklem Toprak Kaybi Esitligi Rehberi. Soil and Water Resources Research Institute of Tokat, Tokat, Turkey, 346 pp.

Oliveira, P., 2005. Erosão e Conservação do Solo em Olivais no Nordeste Trasmontano. Phd thesis, Instituto Politécnico de Bragança, Escola Superior Agrária, Bragança, Portugal, 62 pp.

Owens, P. N., Batalla, R. J., Collins, A. J., Gomez, B., Hicks, D. M., Horowitz, A. J., Kondolf, G. M., Marden, M., Page, M. J., Peacock, D. H., Petticrew, E. L., Salomons, W., Trustrum, N. A., 2005. Fine-grained sediment in river systems: Environmental significance and management issues. River Research and Applications 21 (7), 693-717.

Øygarden, L., 1996. Erosion and surface runoff in small agricultural catchments. In: Walling, D. E., Webb, B. (Eds.), Erosion and Sediment Yield: Global and Regional Perspectives (Proceedings of the Exeter Symposium July 1996). IAHS Publication no. 236. Wallingford, 15-19 July. 236. International Association of Hydrological Sciences, Wallingford, pp. 283-291.

Øygarden, L., Kvaerner, J., Jenssen, P. D., 1997. Soil erosion via preferential flow to drainage systems in clay soils. Geoderma 76 (1-2), 65-86.

Pinczés, Z., 1982. Variations In Runoff And Erosion Under Various Methods Of Protection. In: Walling, D., Hadley, R. (Eds.), Recent Developments in the Explanation and Prediction of Erosion and Sediment Yield (Proceedings of the Exeter Symposion). Wallingford, July 1982. IAHS Publ. 137. International Association of Hydrological Sciences, Wallingford, pp. 49-57.

Postiglione, L., Basso, F., Amato, M., Carone, F., 1990. Effects of soil tillage methods on soil losses, on soil characteristics and on crop production in a hilly area of Southern Italy. Agricoltura Mediterranea 120, 148-158.

Puustinen, M., Koskiaho, J., Peltonen, K., 2005. Influence of cultivation methods on suspended solids and phosphorus concentrations in surface runoff on clayey sloped fields in boreal climate. Agriculture Ecosystems \& Environment 105 (4), 565-579.

Puustinen, M., Tattari, S., Koskiaho, J., Linjama, J., 2007. Influence of seasonal and annual hydrological variations on erosion and phosphorus transport from arable areas in Finland. Soil \& Tillage Research 93 (1), 44-55. 
Quinton, J. N., Catt, J. A., 2004. The effects of minimal tillage and contour cultivation on surface runoff, soil loss and crop yield in the long-term Woburn Erosion Reference Experiment on sandy soil at Woburn, England. Soil Use and Management 20 (3), 343-349.

Ramos, M. C., Martínez-Casasnovas, J. A., 2006. Nutrient losses by runoff in vineyards of the Mediterranean Alt Penedès region (NE Spain). Agriculture, Ecosystems \& Environment 113 (14), 356-363.

Ramos, M. C., Martínez-Casasnovas, J. A., 2007. Soil loss and soil water content affected by land levelling in Penedès vineyards, NE Spain. Catena 71 (2), 210-217.

Renard, K., Foster, G., Weesies, G., McCool, D., Yoder, D., 1997. Predicting soil erosion by water: a guide to conservation planning with the Revised Universal Soil Loss Equation (RUSLE). Agriculture Handbook No. 703. U.S. Department of Agriculture, Agricultural Research Service, Washington DC, 384 pp.

Rivoira, G., Roggero, P., Bullitta, S., 1989. Influenza delle tecniche di miglioramento dei pascoli sui fenomeni erosivi dei terreni in pendio. Rivista di Agronomia 23, 372-377.

Römkens, M., 2010. Erosion and sedimentation research in agricultural watersheds in the USA: from past to present and beyond. In: Banasik, K., Horowitz, A., Owens, P., Stone, M., Walling, D. (Eds.), Sediment Dynamics for a Changing Future (Proceedings of the ICCE symposium held at Warsaw University of Life Sciences -SGGW. Warsaw, Poland, 14-18 June 2010. IAHS Publ. 337. International Association of Hydrological Sciences, Warsaw, Poland, pp. 17-26.

Rockström, J., Karlberg, L., Wani, S. P., Barron, J., Hatibu, N., Oweis, T., Bruggeman, A., Farahani, J., Qiang, Z., 2010. Managing water in rainfed agriculture-The need for a paradigm shift. Agricultural Water Management 97 (4), 543-550.

Romero-Díaz, A., Cammeraat, L. H., Vacca, A., Kosmas, C., 1999. Soil erosion at three experimental sites in the Mediterranean. Earth Surface Processes and Landforms 24 (13), 1243-1256.

Rousseva, S., Lazarov, A., Tsvetkova, E., Marinov, I., Malinov, I., Kroumov, V., Stefanova, V., 2006. Bulgaria. In: Boardman, J., Poesen, J. (Eds.), Soil Erosion in Europe. Wiley, Chichester, pp. $167-181$.

Roxo, M., Cortesao Casimiro, P., Soeiro de Brito, R., 1996. Inner lower Alentejo Field site: cereal cropping, soil degradation and desertification. In: Brandt, J. C., Thornes, J. B. (Eds.), Mediterranean Desertification and Land Use. Wiley, Chichester, pp. 112-228.

Rusinamhodzi, L., Corbeels, M., van Wijk, M., Rufino, M., Nyamangara, J., Giller, K., 2011. A meta-analysis of long-term effects of conservation agriculture on maize grain yield under rain-fed conditions. Agronomy for Sustainable Development 31 (4), 657-673.

Sanchez, J., Mangas, V., Ortiz, C., Bellot, J., 1994. Forest fire effect on soil chemical properties and runoff. In: Sala, M., Rubio, J. L. (Eds.), Soil Erosion and Degradation as a Consequence of Forest Fires. Geoforma Ediciones, Logroño, pp. 53-65.

Schjønning, P., Sibbesen, E., Hansen, A., Hasholt, B., Heidmann, T., Madsen, M., J.D., N., 1995. Erosion plot studies 1989-92: Fit of a simple model to surface runoff from agricultural land. In: Kronvang, B., Svendsen, L. M., Sibbesen, E. (Eds.), Sediment and phosphorus. Erosion and delivery, transport and fate of sediments and sediment-associated nutrients in watersheds. Proceedings from an international workshop held in Silkeborg, Denmark. NERI Tech. Report No. 178. Silkeborg, Denmark, 9-12 October. 178. Ministry of Environment and Energy - Natural Environment Research Institute, Silkeborg, Denmark, pp. 51-52. 
Schnabel, S., González, F., Murillo, M., Moreno, V., 2001. Different Techniques of Pasture Improvement and Soil Erosion in a Wooded Rangeland in SW Spain; Methodology and Preliminary Results. In: Conacher, A. (Ed.), Land Degradation. Kluwer Academic Publishers, Dordrecht, pp. 239-253.

Schreiber, J., Cullum, R., 1998. Tillage effects on surface and groundwater quality in loessial upland soybean watersheds. American Society of Agricultural and Biological Engineers 41 (3), 607-614.

Schwilch, G., Bestelmeyer, B., Bunning, S., Critchley, W., Herrick, J., Kellner, K., Liniger, H. P., Nachtergaele, F., Ritsema, C. J., Schuster, B., Tabo, R., van Lynden, G., Winslow, M., 2011. Experiences in monitoring and assessment of sustainable land management. Land Degradation \& Development 22 (2), 214-225.

Shakesby, R., 2011. Post-wildfire soil erosion in the Mediterranean: Review and future research directions. Earth-Science Reviews 105 (3-4), 71-100.

Shinjo, H., Fujita, H., Gintzbuger, G., Kosaki, T., 2000. Impact of Grazing and Tillage on Water Erosion in Northeastern Syria. Soil Science and Plant Nutrition 46 (1), 151-162.

Shipitalo, M. J., Edwards, W. M., 1998. Runoff and erosion control with conservation tillage and reduced-input practices on cropped watersheds. Soil \& Tillage Research 46 (1-2), 1-12.

Smets, T., Poesen, J., Bochet, E., 2008a. Impact of plot length on the effectiveness of different soil-surface covers in reducing runoff and soil loss by water. Progress in Physical Geography $32(6), 654-677$.

Smets, T., Poesen, J., Knapen, A., 2008b. Spatial scale effects on the effectiveness of organic mulches in reducing soil erosion by water. Earth-Science Reviews 89 (1-2), 1-12.

Suchanic, M., 1987. Assessment of erosion processes and proposed soil conservation measures in period 1986-7 (In Slovak: Zhodnotenie eroznych procesov a navrhnutych protieroznych opatreni v rokoch 1986-7), Research Report. SSCRI, Bratislava, Slovakia.

Syversen, N., 2005. Effect and design of buffer zones in the Nordic climate: The influence of width, amount of surface runoff, seasonal variation and vegetation type on retention efficiency for nutrient and particle runoff. Ecological Engineering 24 (5), 483-490.

Teodorescu, V., Badescu, L., 1988. Cercetari privind eroziunea in suprafata in plantatiile pomicole intensive. Analele I.C.P.A. 49, 225-234.

Tijms, H., 2004. Understanding Probability: Chance Rules in Everyday Life. Cambridge University Press, Cambridge, 380 pp.

Torri, D., Poesen, J., Borselli, L., 1997. Predictability and uncertainty of the soil erodibility factor using a global dataset. Catena 31 (1-2), 1-22.

Turtola, E., Alakukku, L., Uusitalo, R., Kaseva, A., 2007. Surface runoff, subsurface drainflow and soil erosion as affected by tillage in a clayey Finnish soil. Agricultural and Food Science 16 (4), 332-351.

Ulén, B. M., Kalisky, T., 2005. Water erosion and phosphorus problems in an agricultural catchment - Need for natural research for implementation of the EU Water Framework Directive. Environmental Science \& Policy 8 (5), 477-484.

Unger, P. W., Vigil, M. F., 1998. Cover crop effects on soil water relationships. Journal of Soil and Water Conservation 53 (3), 200-207. 
Uusi-Kämppä, J., 2005. Phosphorus purification in buffer zones in cold climates. Ecological Engineering 24 (5), 491-502.

Van den Putte, A., Govers, G., Diels, J., Gillijns, K., Demuzere, M., 2010. Assessing the effect of soil tillage on crop growth: A meta-regression analysis on European crop yields under conservation agriculture. European Journal of Agronomy 33 (3), 231-241.

Vanmaercke, M., Poesen, J., Maetens, W., de Vente, J., Verstraeten, G., 2011a. Sediment yield as a desertification risk indicator. Science of The Total Environment 409 (9), 1715-1725.

Vanmaercke, M., Poesen, J., Verstraeten, G., de Vente, J., Ocakoglu, F., 2011b. Sediment yield in Europe: Spatial patterns and scale dependency. Geomorphology 130 (3-4), 142-161.

Vanmaercke, M., Zenebe, A., Poesen, J., Nyssen, J., Verstraeten, G., Deckers, J., 2010. Sediment dynamics and the role of flash floods in sediment export from medium-sized catchments: a case study from the semi-arid tropical highlands in northern Ethiopia. Journal of Soils and Sediments 10 (4), 611-627.

Verstraeten, G., Poesen, J., 1999. The nature of small-scale flooding, muddy floods and retention pond sedimentation in central Belgium. Geomorphology 29 (3-4), 275-292.

Viguier, J., 1993. Mesure et modélisation de l'érosion pluviale. Application au vignoble de Vidauban (Var). Phd. thesis, Université d'Aix-Marseille, France, Faculté des Sciences de Luminy, Marseille, 293 pp.

Voss, W., 1978. Ermittlung der Nährstoffumlagerung durch Erosion und Charakterisierung der Erosionsfracht einiger Vorfluter in hessischen Mittelgebirgs-Kleinlandschaften. Diss. thesis, Univ. Gießen, Germany, Gießen, 263 pp.

Wainwright, J., Thornes, J., 2004. Environmental Issues in the Mediterranean: Processes and perspectives from the past and present. Routledge, London, $479 \mathrm{pp}$.

Wallace, J. S., 2000. Increasing agricultural water use efficiency to meet future food production. Agriculture, Ecosystems \& Environment 82 (1-3), 105-119.

Warsta, L., Paasonen-Kivekäs, Karvonen, T., Taskinen, A., 2009. Modelling surface and subsurface flow of water and erosion at clayey, subsurface drained agricultural field. In: Anderssen, R., Braddock, R., Newham, L. (Eds.), 18th World IMACS Congress and MODSIM09 International Congress on Modelling and Simulation. Modelling and Simulation Society of Australia and New Zealand and International Association for Mathematics and Computers in Simulation. Cairns, Australia, 13-17 July, pp. 1901-1907.

Williams, A. G., Ternan, J. L., Elmes, A., Tanago, M. G., Blanco, R., 1995. A field study of the influence of land management and soil properties on runoff and soil loss in central Spain. Environmental Monitoring and Assessment 37 (1), 333-345.

Zanchi, C., 1983. Influenza dell'azione battente della pioggia e del ruscellamento nel processo erosivo e variazioni dell'erodibilità del suolo nei diversi periodi stagionali. Annali Instituto Sperimentale Studio E Difessa Suolo - Firenze XIV, 347-358. 